\title{
Facilitators to health policy and management knowledge translation: A scoping review
}

\author{
Ali Mohammad Mosadeghrad ${ }^{1}$, Parvaneh Isfahani ${ }^{2 *}$ \\ 1. Health Information Management Research Center, School of Public Health, Tehran University of Medical Sciences, Tehran, Iran \\ 2. School of Public Health, Zabol University of Medical Sciences, Zabol, Iran
}

Received: 28 April 2020

Accepted for publication: 1August 2021

[EPub a head of print-7 September 2021]

Payesh: 2021; 20 (5): 529- 548

\begin{abstract}
Objective (s): Health policy and management knowledge translation is the 'process of production, exchange and use of valid and quality knowledge for health policy makers and managers'. There is a Know-do gap in health policy and management. This study aimed to identify facilitators of knowledge translation in health policy and management.

Methods: This was a scoping review. All published articles on the facilitators to knowledge translation in health policy and management from 1 January 2002 to 20 March 2021 in nine databases were searched. Finally, 49 documents were reviewed and analyzed using MAXQDA software.

Results: Overall 59 facilitators to health policy and management knowledge translation were identified and were grouped into seven categories including factors related to the characteristics of the healthcare system, the healthcare organization, the health policy and management knowledge, the knowledge producer, the knowledge user, the knowledge transfer technology and the communication between the knowledge producer and the user. Improving communication between researchers and policymakers and managers, generating applied knowledge, increasing access to valid evidence, developing knowledge producers' and users' skills, increasing collaboration between researchers and policymakers and managers, and increasing research resources were the most often reported facilitators to knowledge translation in health policy and management.

Conclusion: Researchers should be encouraged to produce applied knowledge and policymakers and managers should be encouraged to use research evidence in their decision-making. Appropriate policies, strategies, methods, and standards should be used to make more use of the knowledge generated in health policy and management.
\end{abstract}

Key words: Knowledge translation, Facilitators, Healthcare policy, Health management, Scoping review

\footnotetext{
${ }^{*}$ Corresponding author: School of Public Health, Zabol University of Medical Sciences, Zabol, Iran

E-mail: p.isfehani@mail.com
} 


\title{
تسهيل كننده هاى ترجمان دانش سياست كذارى و مديريت سلامت: يك مرور حيطه اى
}

\author{
على محمد مصدق راد'؛ يروانه اصفهانى \\ I. دانشكده بهداشت، مركز تحقيقات مديريت اطلاعات سلامت، دانشحاه علوم يزشكى تهران، تهران، ايران

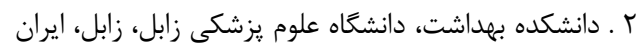

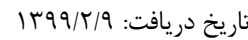

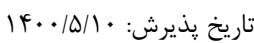

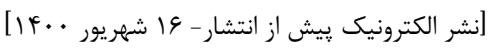

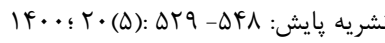

جكيده

مقدمه: ترجمان دانش سياستخذارى و مديريت سلامت فرايند توليد، تبادل و استفاده از دانش معتبر و با كيفيت براى سياستگذارى و مديريت نظام سلامت

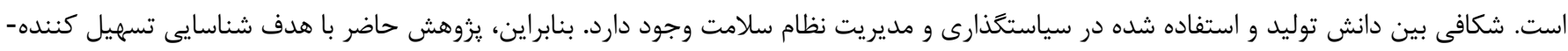

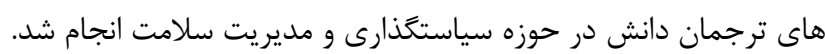

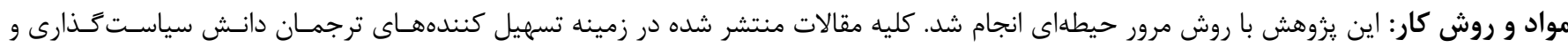

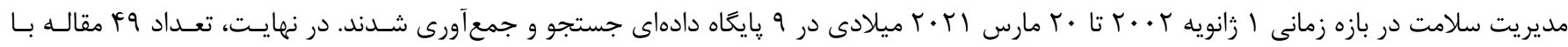

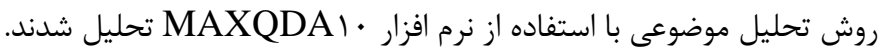

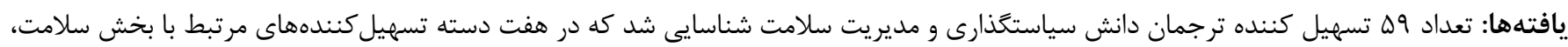

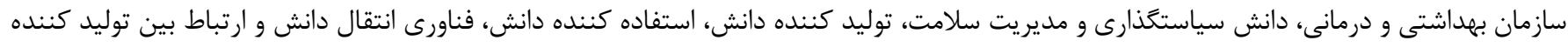

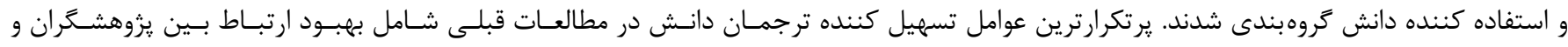

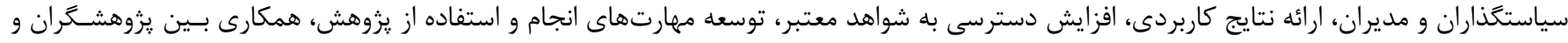

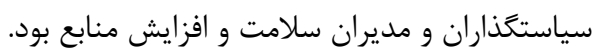

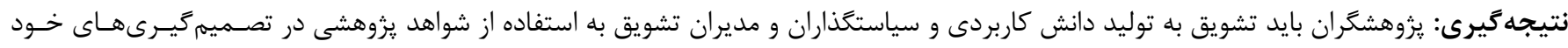

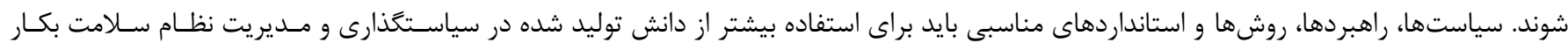
كرفته شود. كليدوازه: ترجمان دانش، تسهيل كننده، سياستخذارى سلامت، مديريت سلامت، مرور حيطه اى 
براى سياستگذارى و مديريت نظام سلامت است [ب]. ترجمان دانش

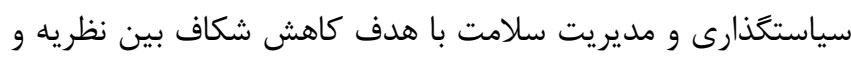

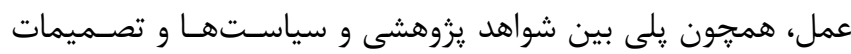

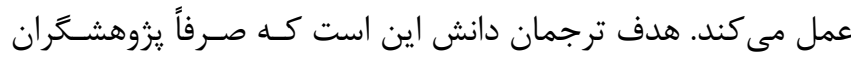

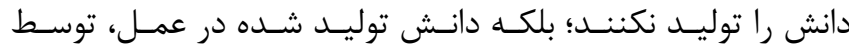

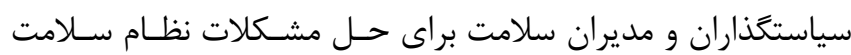
استفاده شود. ترجمان دانش سياستخذارى و مديريت سلامت فرائ سرايند

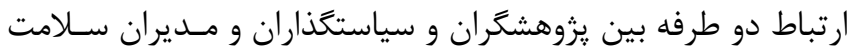
است كه بر اساس آن يزوهشكران با توجه به نيازهاى سياسـتخذاران

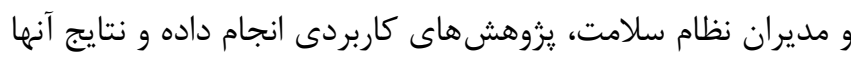
توسط سياستگذاران و مديران سلامت استفاده مىشود.

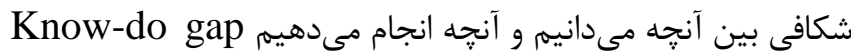

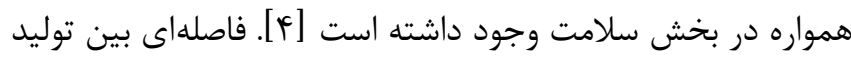

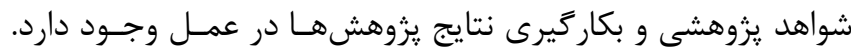

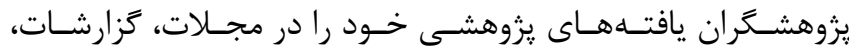

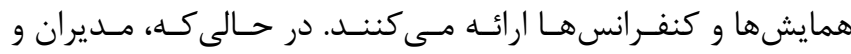
كاركنان كمتر از اين شواهد يزوهشى در عمل استفاده مى كنند [ه]].

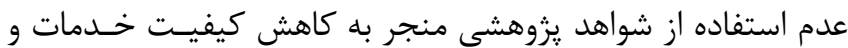

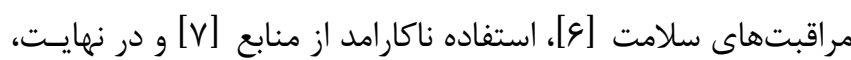

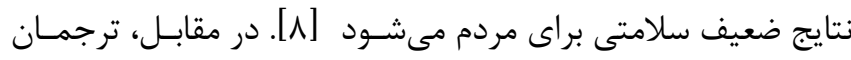

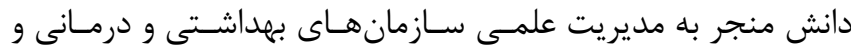

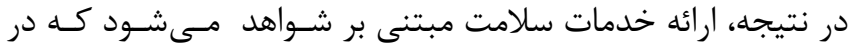

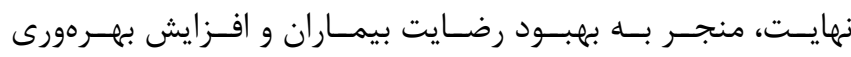

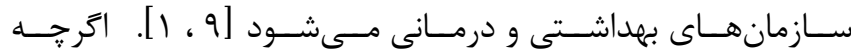

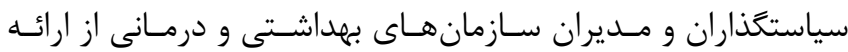

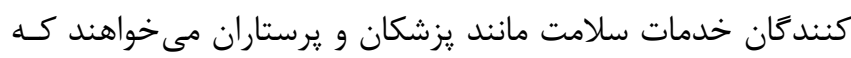

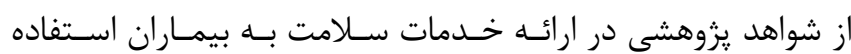

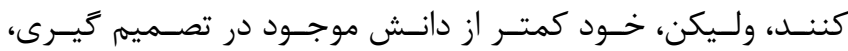

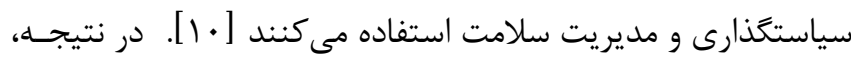

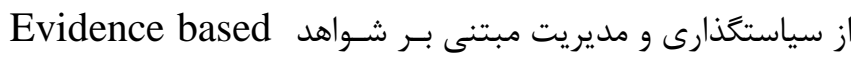
Policy making and management مراقبت مبتنى بر شـواهد Evidence based practice

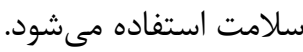
عوامل مرتبط با ظرفيت، علاقه، توانـايى و مههارت توليدكنـــــان و و

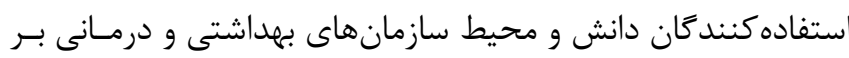

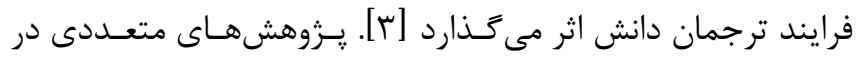

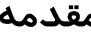

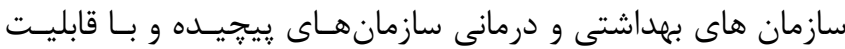
تطبيق بسيار بالا هستند كه در يك محيط متغير فعاليت مى كنــــد. در نتيجه، مديران بهداشتى و درمانى بايد تصميماتى اتخاذ كنند تـا

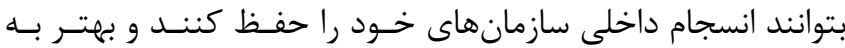

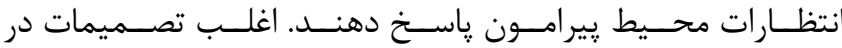

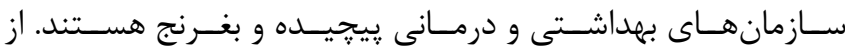

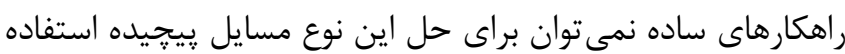

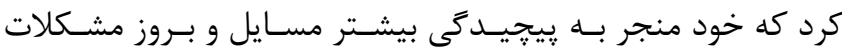

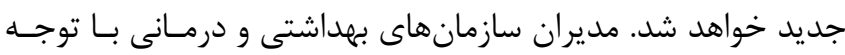

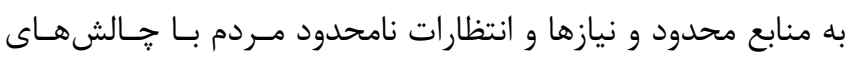

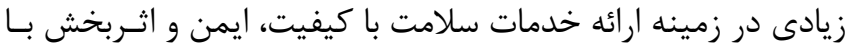

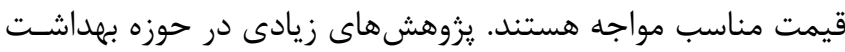

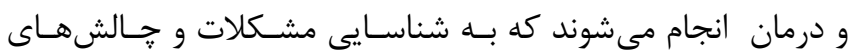
سازمان هاى بهداشتى و درمانى و راهكارهاى مــوثر بـــاى رفـع آنهـا

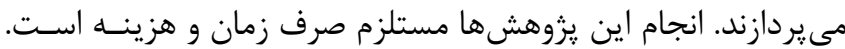

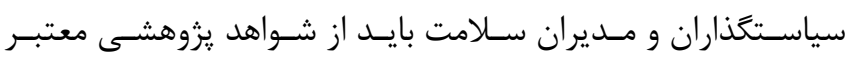

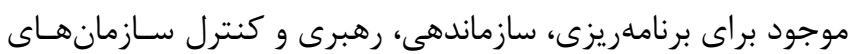

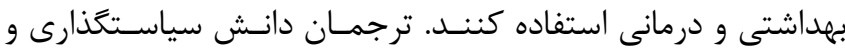

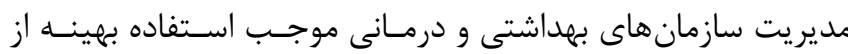

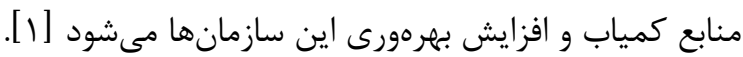

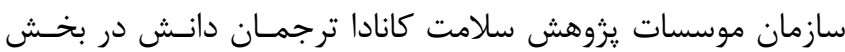

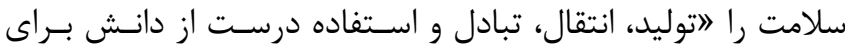

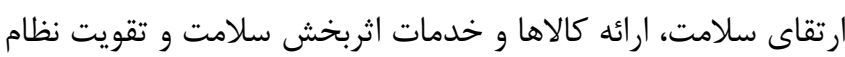

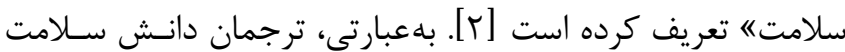

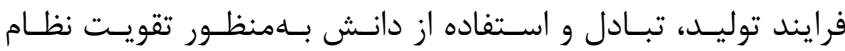
سلامت، بهبود فرايندهاى كارى، توليد و ارائه كالاها و خدمات مـؤثر

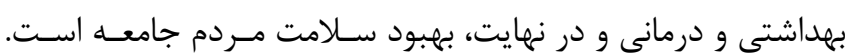
ترجمــان دانسش Knowledge translation فراتـر از ترجمــان

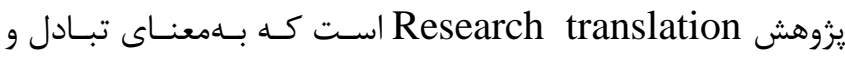

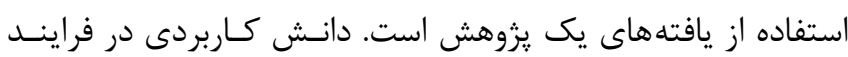
ترجمان دانش، منتقل، دريافت، تطبيق و استفاده مىشود. يافتههاى

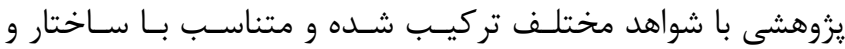

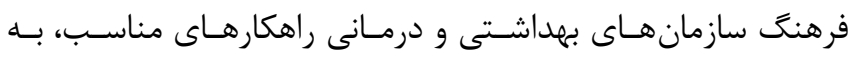

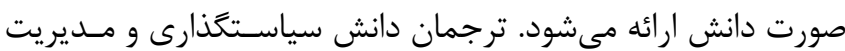

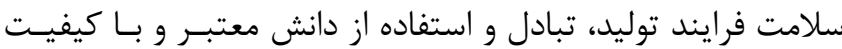


انتخاب مطالعات، ترسيم دادهها، جمعآورى، خلاصهسازى و كَزارش

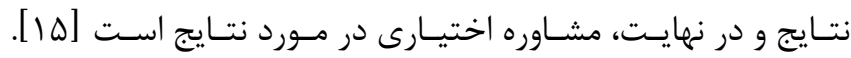

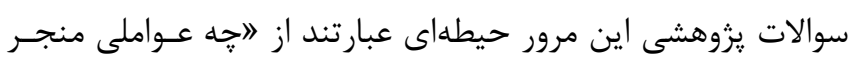

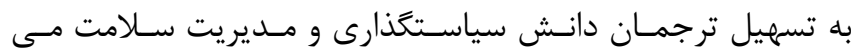

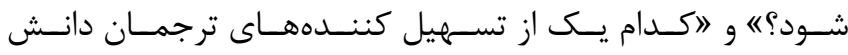

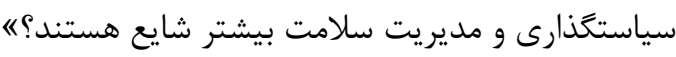

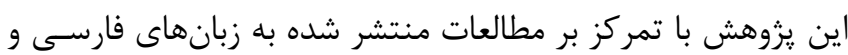

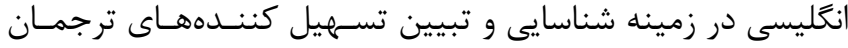

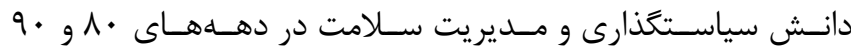

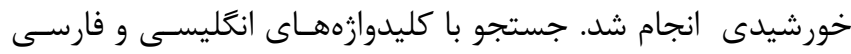
Knowledge 》، “Factor»، “Enabler»، “Facilitactor» مناسب Knowledge » «Knowledge translation»، «generation “Knowledge exchang» «Knowledge uptake» «transfer Health » «Health policy» «Knowledge mobilization» Healthcare » «Health management»، «policy making ״organization "اتسهيل كننده)، "توانمندساز"، "سياستخذارى سلامت"، الهديريت

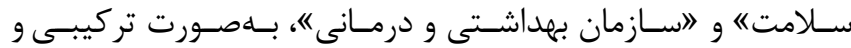

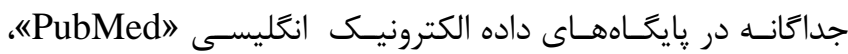
، «Springer» «Emerald» «SScience Direct» «SScopus» "Web of Science»

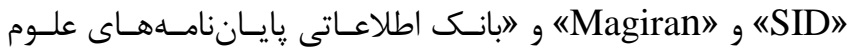
يزشكى كشور" انجام شد (جدول (). همجنــين، موتسور جسـتجوى هGoogle scholar»

$$
\text { مناسب جستجو شد. }
$$

علاوه براين، مجلات تخصصى در حوزه مديريت اطلاعـات و دانشـ

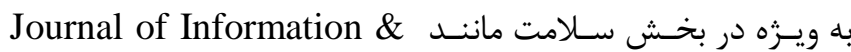
Knowledge and Knowledge Management Journal of Knowledge .Information Systems Interdisciplinary Journal of ،Management information Knowledge Management for IInformation Journal of Information \& .Development Journal Knowledge Management

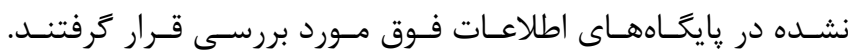
مطالعات بازيابى شده وارد نرمافزار

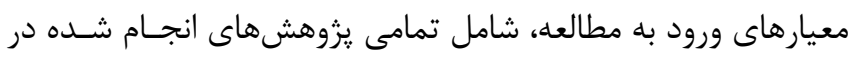

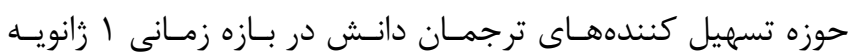

جهان در زمينه تسهيل كنندههاى ترجمان دانش انجام شـده اسـت

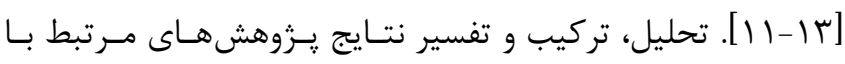

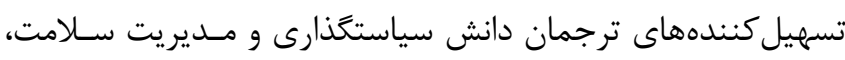

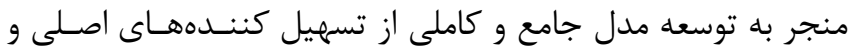

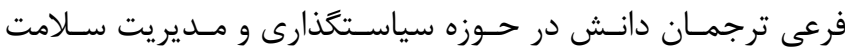

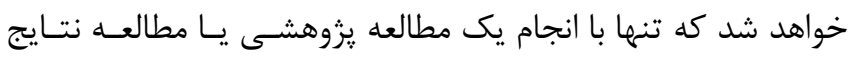

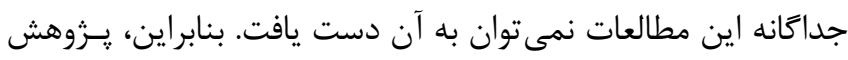

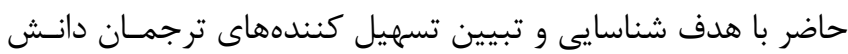

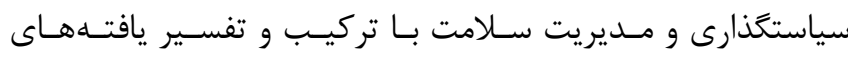

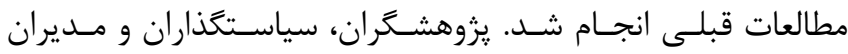

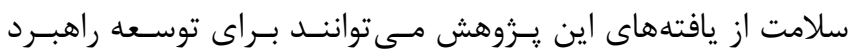

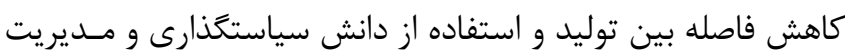

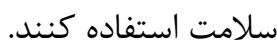

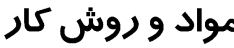

مطالعه حاضر بــا روش مـرور حيطـهاى Scoping review انجـام شد. مرور حيطهاى يك يزوهش ثانويه است كه به تركيب و تحليـل

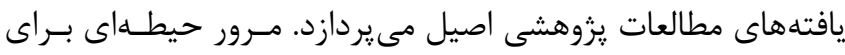

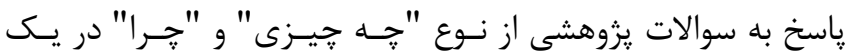
حيطه موضوعى خاص مفيد است. از مطالعه مرور حيطهاى مى دــوان

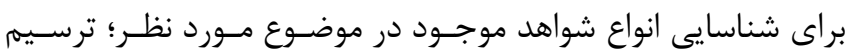
نقشه ادبيات موضوع مربوطه، بيان كليت موضـوع، اجـزاء و مفــاهيم

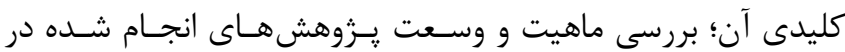

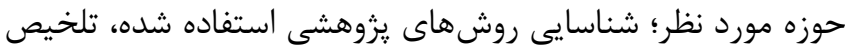

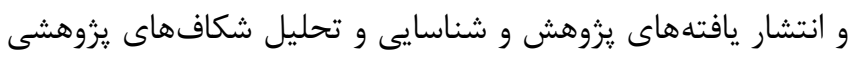

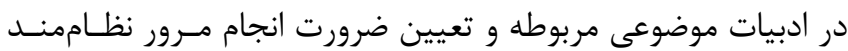
استفاده كرد. مطالعه مرور حيطهاى علاوه بر مقالات يزوهشى اصـيل

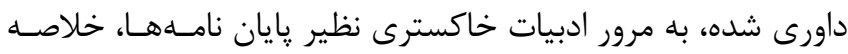

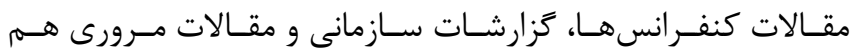
مى يردازد. در مرور حيطهاى از روش جستجوى نظـاممنــد اسـتفاده

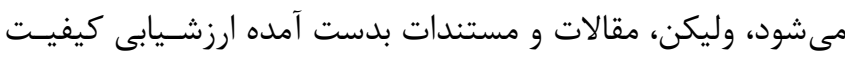

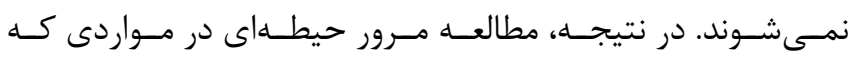

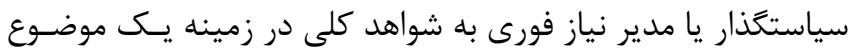

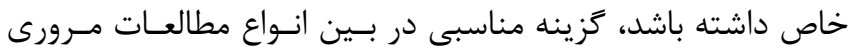

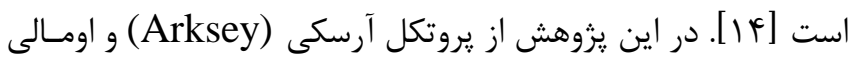

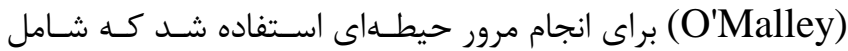

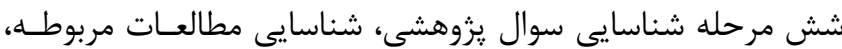




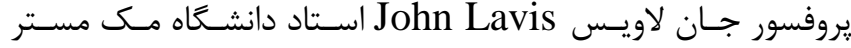

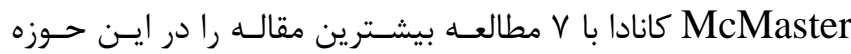

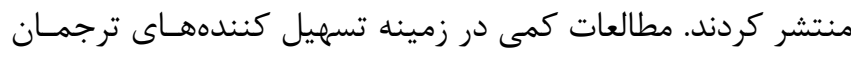

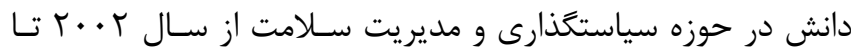

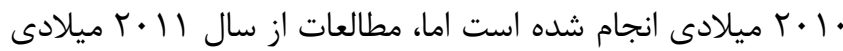

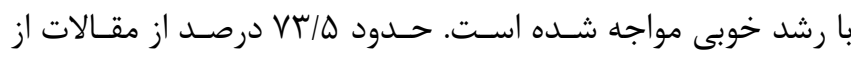

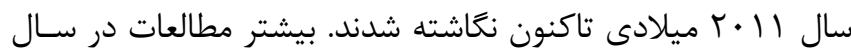

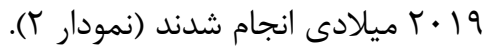

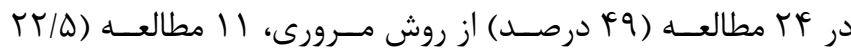

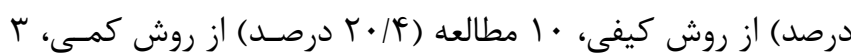

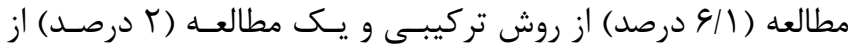

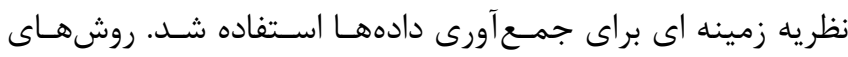

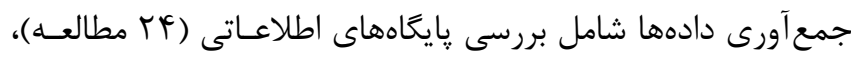

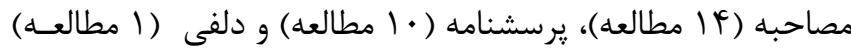

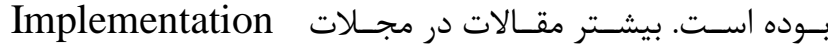
Health Research Policy and Science Systems Bulletin of the World Health Organization و PloS one (r مقاله) به جاب رسيدند.

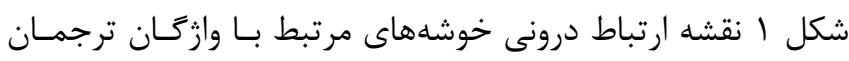

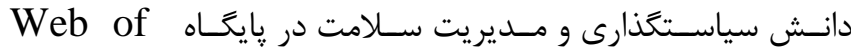

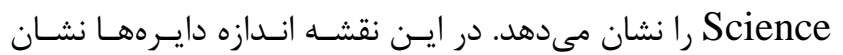

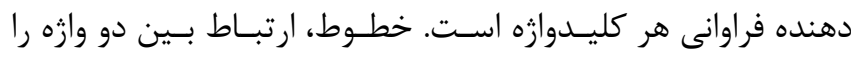
نشان مى دهد و ضخامت خطوط بيانكر ميزان اين ارتباط است. وازهـ-

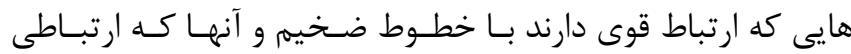
ضعيفى دارند با خطوط نازكتر مشخص شدند. در اين نقشه، تهار ارنار خوشه براى حوزه ترجمان دانش بيان شد. خوشه اول شامل ده آيتم

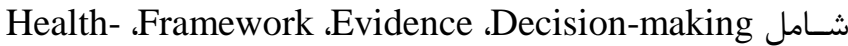
Public ،Organizations ،Knowledge exchange policy Support و Strategies ،Research ،health بود. خوشـه دوم در

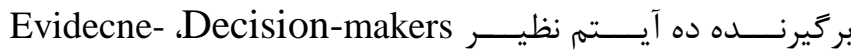
Health ،Government ،Faciliators informed decision ،Knowledge transfer Implementation policy Researchers و Quality ،Knowledge translation

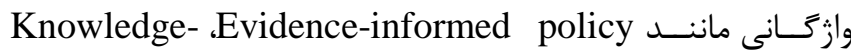
Systemtic g Support tools ،Management translation

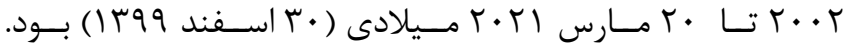

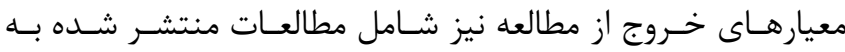

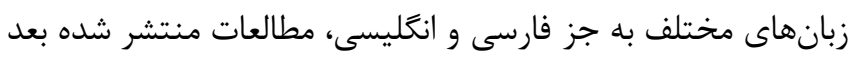

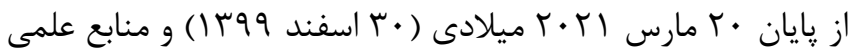

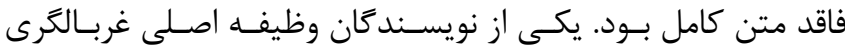

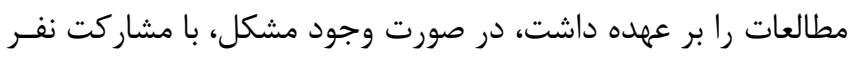
دوم و بحث و تبادل نظر، اجماع حاصل مى رشد.

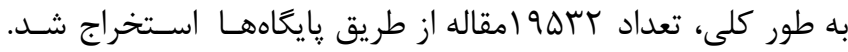

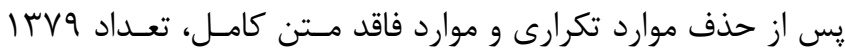

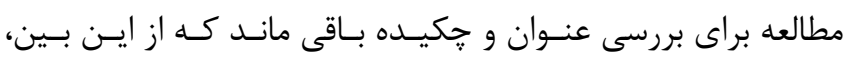

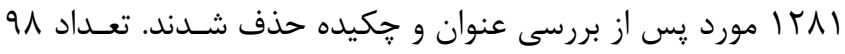

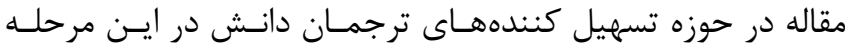

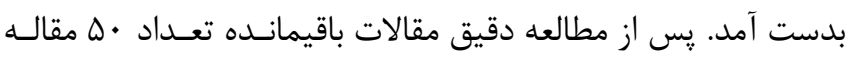

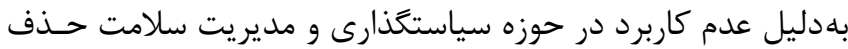

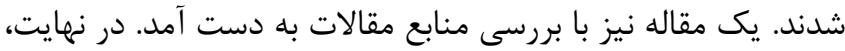

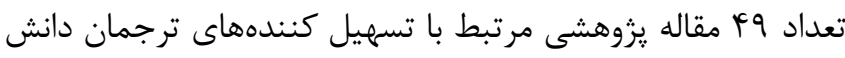

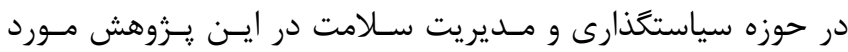
استفاده قرار كرفتند (جدول أو و نمودار (). از فرم استخراج دادهها شامل قسمت هاى مشخصات نويسندكان، نام مجله، سال انتشار مقاله، كشور محل مطالعـه، هــدف مطالعـه، سـال

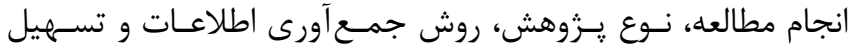

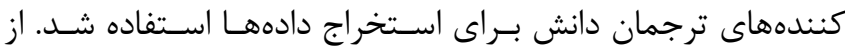

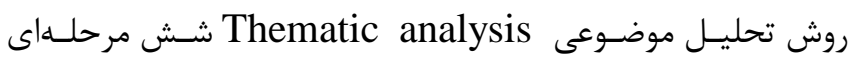
براون و كلارك شامل آشنايى بــا دادهــا، شناسـايى كـدهاى اوليـه، جستجو براى درون مايه ها، مرور درون مايه ها ، تعريف درون مايسهـ ها و تهيه كزارش براى تحليل دادههاى كيفى اين مطالعـه اسـتفاده

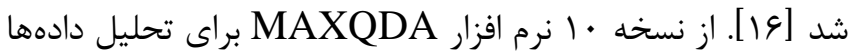

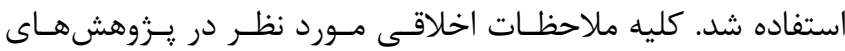

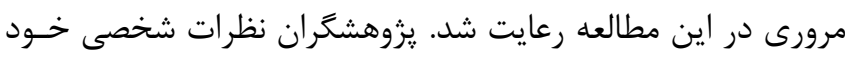

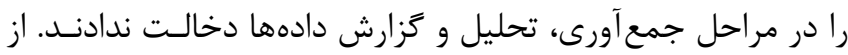
جك ليست PRISMA-ScR براى كزارش دهى يافتههـا اسـتفاده

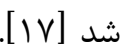

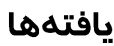

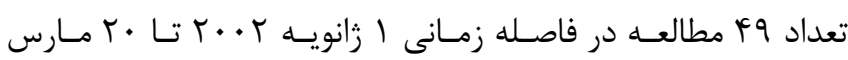

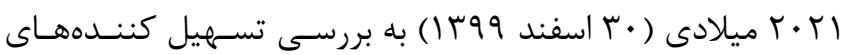

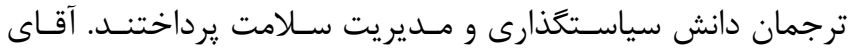




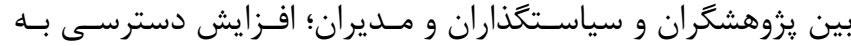

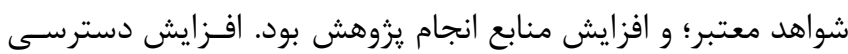

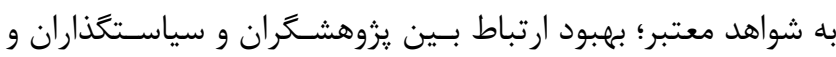

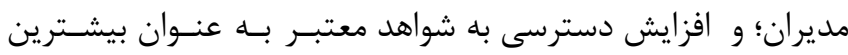

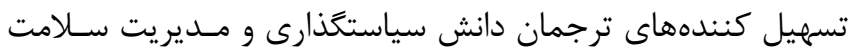

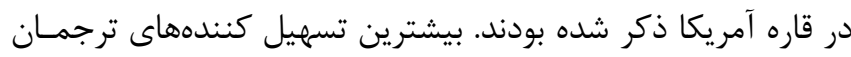

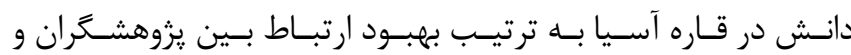
سياستخذاران و مديران؛ ايجاد فرهنگ تصميم گيرى مبتنى بر شـواهد؛

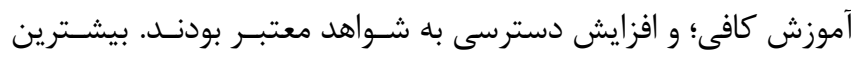

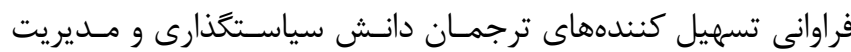

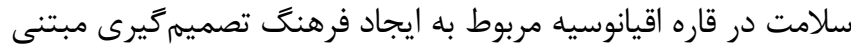

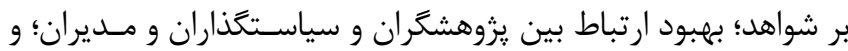

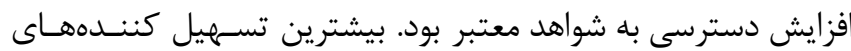

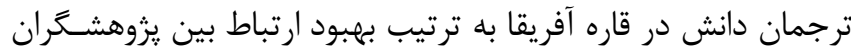

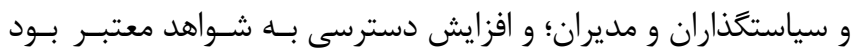

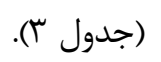

مدل مفهومى تسهيل كنندههاى ترجمان دانسش سياسـتَذارى و

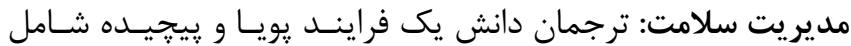

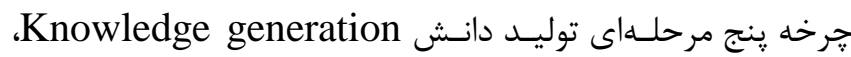

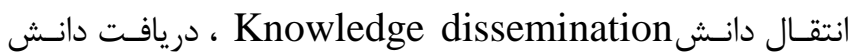
Knowledge تطبيـق دانـشـ Knowledge reception

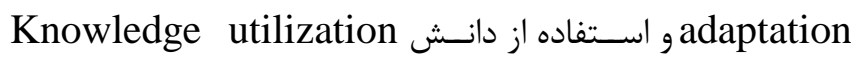

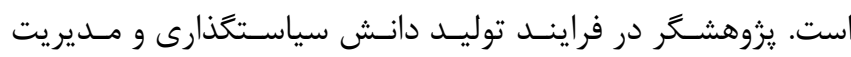

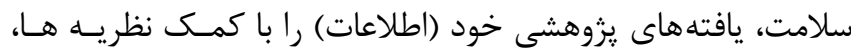

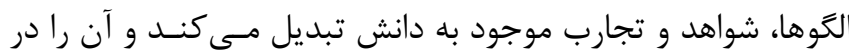

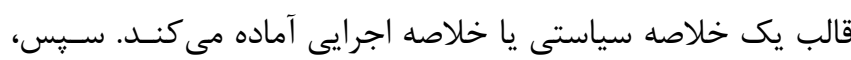

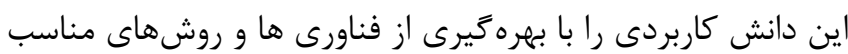

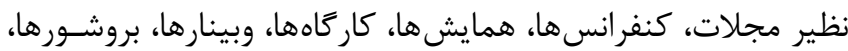

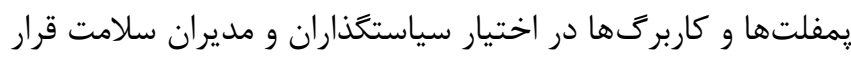

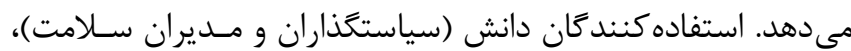

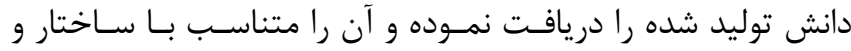

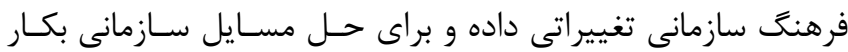

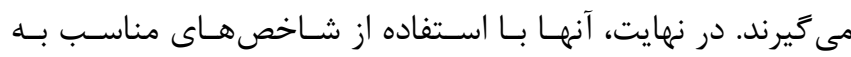
ارزشيابى ميـزان اثربخشى دانسش مـورد اسـتفاده در حـل مســايل

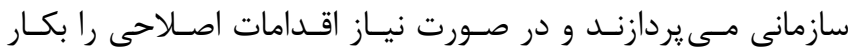

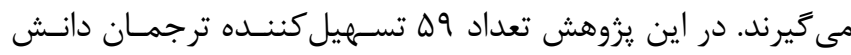

review در خوشه سوم قرار دارند. در خوشه جهارم وازگًانى نظيـر و Public-health Information ،Evidence-based policy Research utilisation

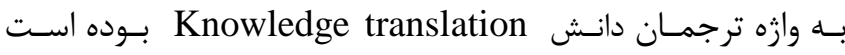
(شكل (). مطالعات تسهيل كننده هاى ترجمان دانش سياستكذارى ترى

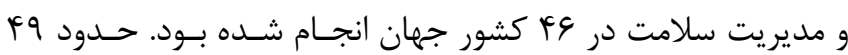
درصد يزوهشها در قاره آمريكا (كانادا، مكزيك، آرزانتـين، اروكوئهـ،

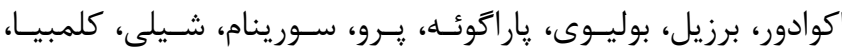

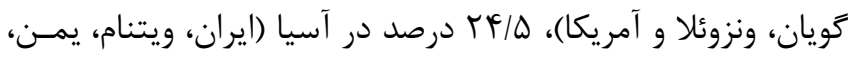

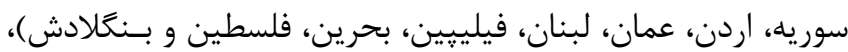

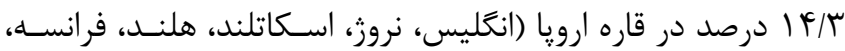

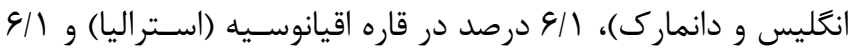
درصد در قاره آفريقا (سودان، ليبى، مراكش، مصر، كنيا، غنا، اوكاندا، نيجريه، مالاوى و آفريقاى جنوبى) انجام شده بود (شـكل كا). تعـداد

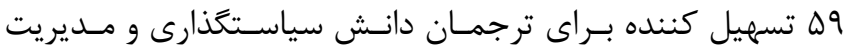

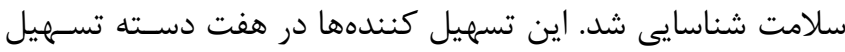

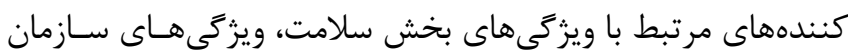

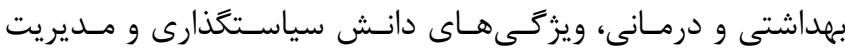

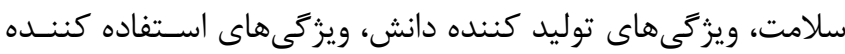

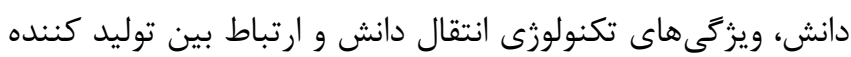

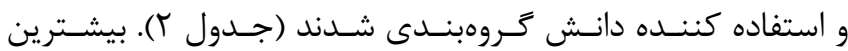
تسهيل كنندههاى ذكر شده ترجمان دانش سياستخذارى و مديريت

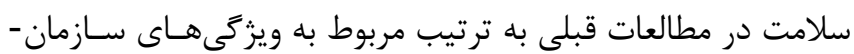

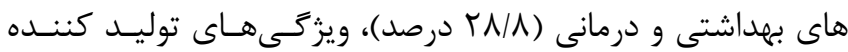

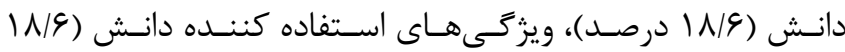

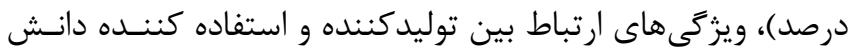

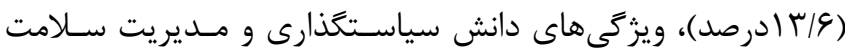

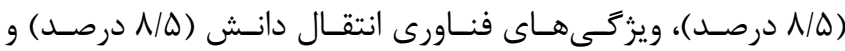

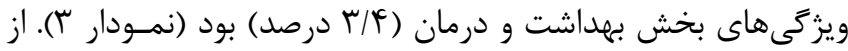
نظر فراوانى بيشترين تسهيل كنندههاى ترجمان دانسش بــه ترتيسب

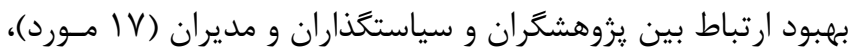

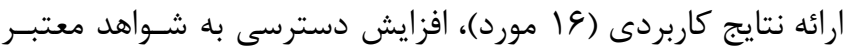

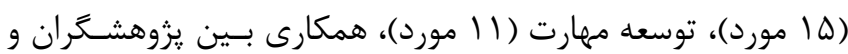

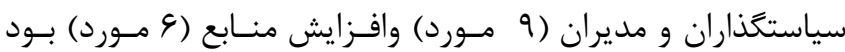

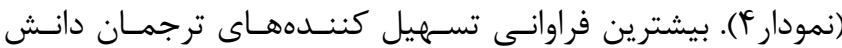

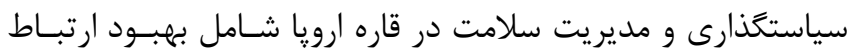


سال بيستم، شماره ينجم، مهر - آبان .. 1F

كانش، تكنولوزى انتقال دانش و ارتباط بين توليد كنـــده و اسـتفاده

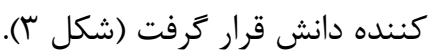

$$
\begin{aligned}
& \text { سياستخذارى و مديريت سلامت شناسايى شـد كـه در هفـت گَروه }
\end{aligned}
$$

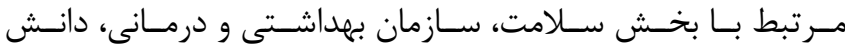

$$
\begin{aligned}
& \text { سياستخذارى و مديريت سلامت، توليد كننده دانش، استفاده كنـــده }
\end{aligned}
$$

\begin{tabular}{|c|c|c|}
\hline مطالعات شناسايى شده & كليدوازٔها و استراتزى جستجو & \\
\hline rAS & $\begin{array}{l}\text { (("facilitate"[All Fields] OR "facilitated"[All Fields] OR "facilitates"[All Fields] OR "facilitating"[All } \\
\text { Fields] OR "facilitation"[All Fields] OR "facilitations"[All Fields] OR "facilitative"[All Fields] OR } \\
\text { "facilitator"[All Fields] OR "facilitator s"[All Fields] OR "facilitators"[All Fields] OR ("enable"[All } \\
\text { Fields] OR "enabled"[All Fields] OR "enablement"[All Fields] OR "enablements"[All Fields] OR } \\
\text { "enabler"[All Fields] OR "enablers"[All Fields] OR "enables"[All Fields] OR "enabling"[All Fields]) OR } \\
\text { ("factor"[All Fields] OR "factor s"[All Fields] OR "factors"[All Fields])) AND ("Knowledge } \\
\text { generation"[All Fields] OR "Knowledge translation"[All Fields] OR "Knowledge transfer"[All Fields] } \\
\text { OR "Knowledge uptake"[All Fields] OR "Knowledge exchange"[All Fields] OR "Knowledge } \\
\text { mobilization"[All Fields]) AND ("health policy"[All Fields] OR "health management"[All Fields])) AND } \\
\text { ((ffrft[Filter]) AND (1000/1/1:2021/3/20[pdat])) }\end{array}$ & PubMed \\
\hline rri & $\begin{array}{l}\text { (TS=(facilitator OR enable OR factor) AND TS=("Knowledge generation" OR "Knowledge } \\
\text { translation" OR "Knowledge transfer" OR "Knowledge uptake" OR "Knowledge exchange" OR } \\
\text { "Knowledge mobilization") AND TS=("health policy-making" OR "health policy" OR "health } \\
\text { management")) AND LANGUAGE: (English OR Persian) Timespan: All years. Indexes: SCI- } \\
\text { EXPANDED, SSCI, A\&HCI, CPCI-S, CPCI-SSH, BKCI-S, BKCI-SSH, ESCI, CCR-EXPANDED, IC. }\end{array}$ & Web of Science \\
\hline ril & $\begin{array}{l}\text { ALL ((facilitator OR enable OR factor) AND ("Knowledge generation" OR "Knowledge translation" } \\
\text { OR "Knowledge transfer" OR "Knowledge uptake" OR "Knowledge exchange" OR "Knowledge } \\
\text { mobilization") AND ("health policy" OR "health management")) AND (LIMIT-TO (PUBSTAGE, } \\
\text { "final")) AND (LIMIT-TO (OA, "all")) AND (LIMIT-TO (DOCTYPE, "ar") OR LIMIT-TO } \\
\text { (DOCTYPE, "re") OR LIMIT-TO (DOCTYPE, "bk") OR LIMIT-TO (DOCTYPE, "ch" ) OR } \\
\text { LIMIT-TO (DOCTYPE, "cp") OR LIMIT-TO (DOCTYPE, "no") OR LIMIT-TO (DOCTYPE, } \\
\text { "ed" ) OR LIMIT-TO ( DOCTYPE, "sh") OR LIMIT-TO ( DOCTYPE, "le") OR LIMIT-TO ( } \\
\text { DOCTYPE, "Undefined")) AND (LIMIT-TO ( SUBJAREA , "HEAL")) AND (LIMIT-TO ( } \\
\text { LANGUAGE, "English") OR LIMIT-TO (LANGUAGE, "Persian" )) }\end{array}$ & Scopus \\
\hline ه ه (ه صفحه اول) & $\begin{array}{l}\text { (facilitator OR enable OR factor) AND ("Knowledge generation" OR "Knowledge translation" OR } \\
\text { "Knowledge transfer" OR "Knowledge uptake" OR "Knowledge exchange" OR "Knowledge } \\
\text { mobilization") AND ("health policy" OR "health management")' } \\
\text { within Medicine \& Public Health, Health Administration, Health Policy, English }\end{array}$ & Springer \\
\hline ra & $\begin{array}{l}\text { (facilitator) AND ("Knowledge generation" OR "Knowledge translation" OR "Knowledge transfer" OR } \\
\text { "Knowledge uptake" OR "Knowledge exchange" OR "Knowledge mobilization") AND ("health policy" } \\
\text { OR "health management") }\end{array}$ & Science Direct \\
\hline$\Delta \cdot F$ & $\begin{array}{l}\text { (facilitator OR enable OR factor) AND ("Knowledge generation" OR "Knowledge translation" OR } \\
\text { "Knowledge transfer" OR "Knowledge uptake" OR "Knowledge exchange" OR "Knowledge } \\
\text { mobilization") AND ("health policy" OR "health management") }\end{array}$ & Emerald \\
\hline له IVA... & & Google scholar \\
\hline 11 & ترجمان-دانش و سلامت & MagIran \\
\hline 9 & & SID \\
\hline 10 & ترجمار & $\begin{array}{lr}\text { Database } & \text { of } \\
\text { Medical } & \text { Sciences } \\
\text { Theses }\end{array}$ \\
\hline 1 & & $\begin{array}{l}\text { Bibliography of } \\
\text { the included } \\
\text { papers }\end{array}$ \\
\hline 19DTr & & مطالعات نهايى \\
\hline
\end{tabular}

جدول ا: راهبرد جستجو و تعداد مطالعات به دست آمده از يايگاههاى مورد بررسى 


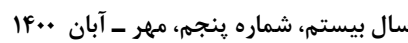

نشريه يزوهشكده علوم بهداشتى جهاددانشكاهى

جدول r: تاكسونومى تسهيل كنندههاى ترجمان دانش سياستخذارى و مديريت سلامت

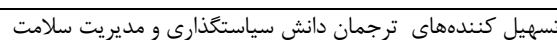

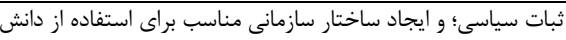

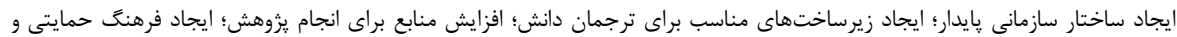

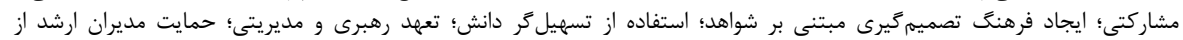

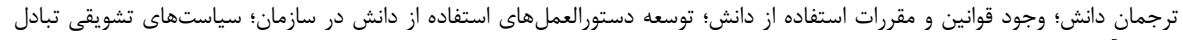

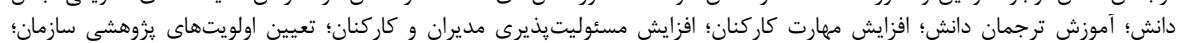

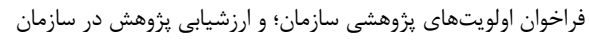

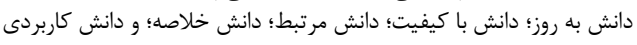

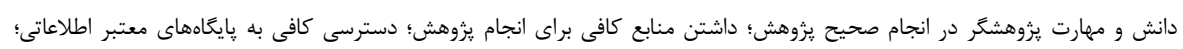

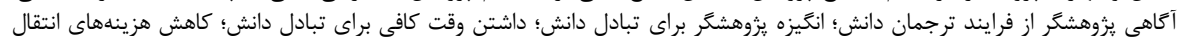

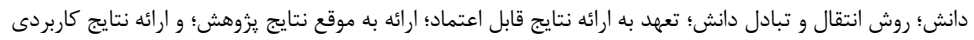

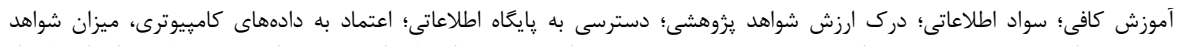

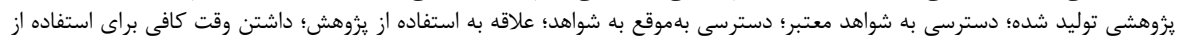

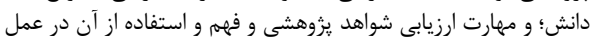

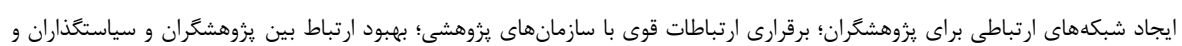

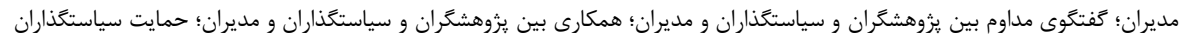

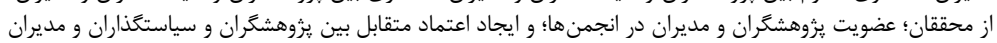

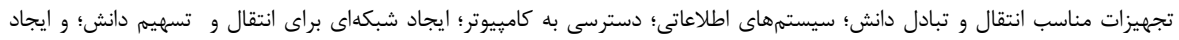

عوامل مرتبط با بخش سلامت

عوامل مرتبط با سازمانهاى بهداشتى و درمانى

عوامل مرتبط با دانش سياستخذارى و مديريت سلامت

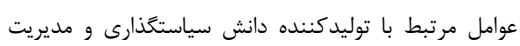
سلامت مرت مرت

عوامل مرتبط با استفاده كننده دانش سياستگذارى و مديريت سلامت مرل مرت عوامل مرتبط با ارتباطات بين توليدكننده و استفاده كننده دانش عوامل مرتبط با تكنولوزى انتقال دانش

جدول بّ: بيشترين تسهيل كنندههاى ترجمان دانش سياست تذارى و مديريت سلامت در قارههاى جهان

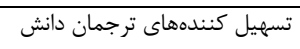

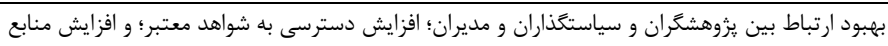

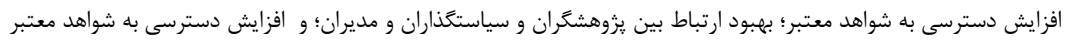

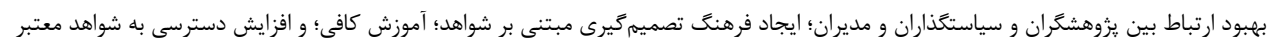

تعداد مقالات حاصل از جستجو در پِيخاهها=190rYr

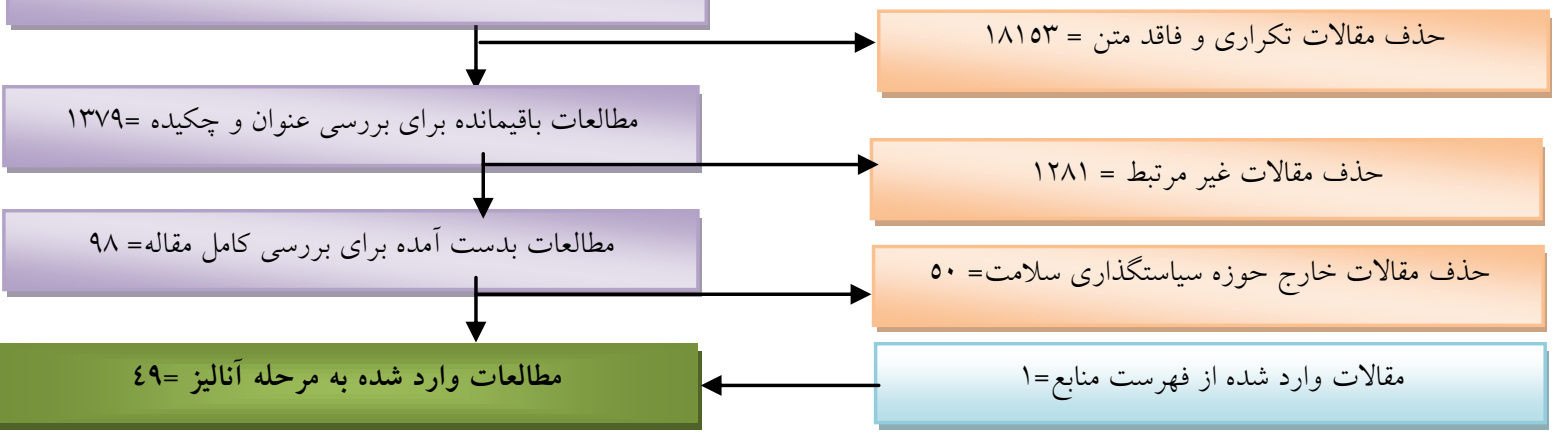

نمودار ا: روند بررسى پايكًاهها و يافتن مقالات 


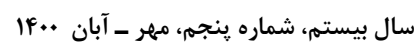
$\overbrace{4}^{\infty}$

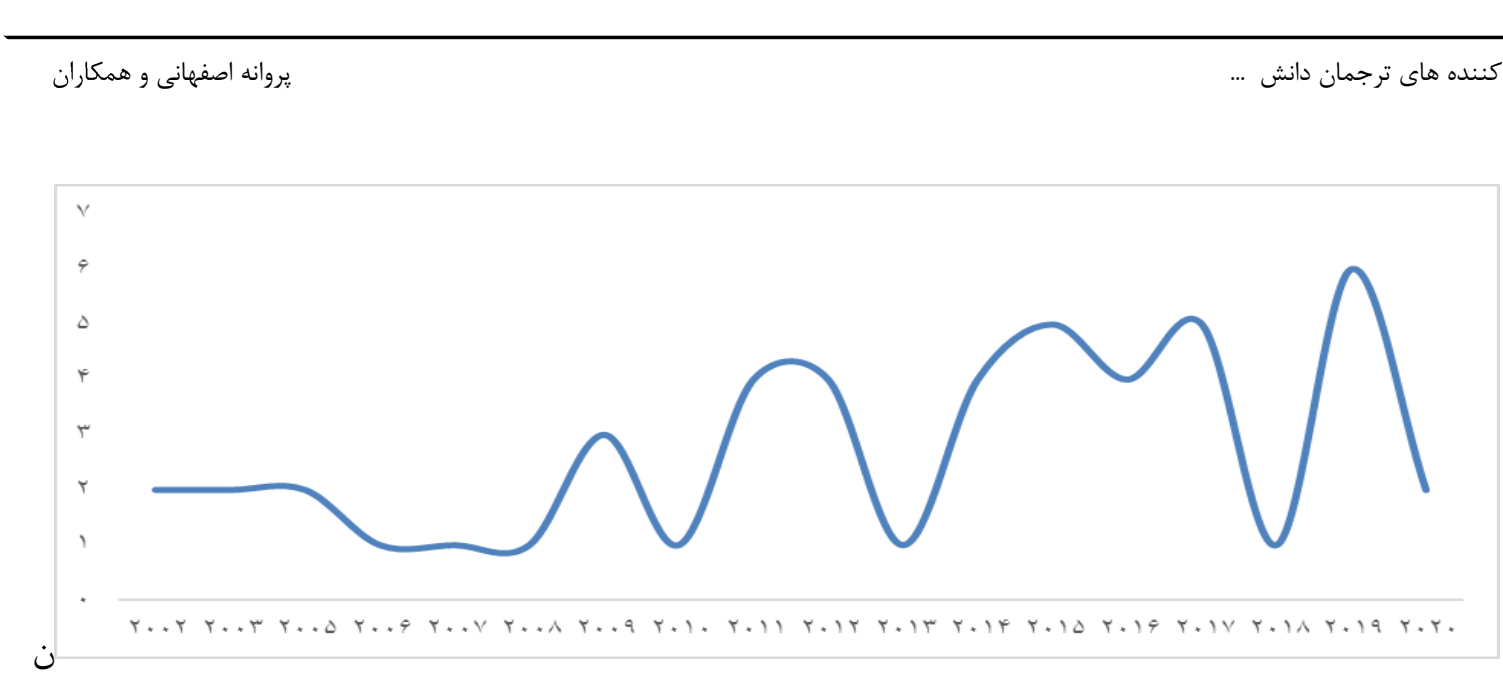

نمودار r: ت توزيع فراوانى مقالات مورد بر رسى برحسب سال

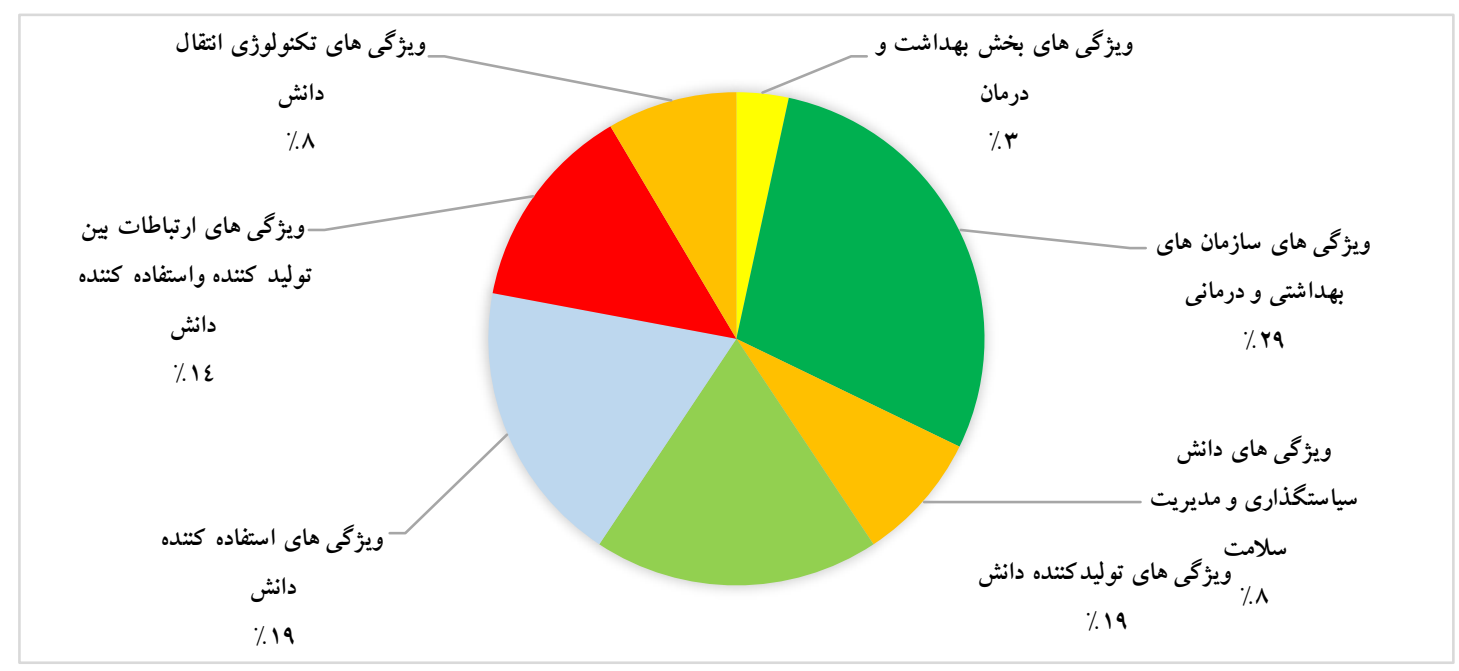

نمودار بّ: توزيع فراوانى تسهيل كنندههاى ترجمان دانش سياستگذارى و مديريت سلامت

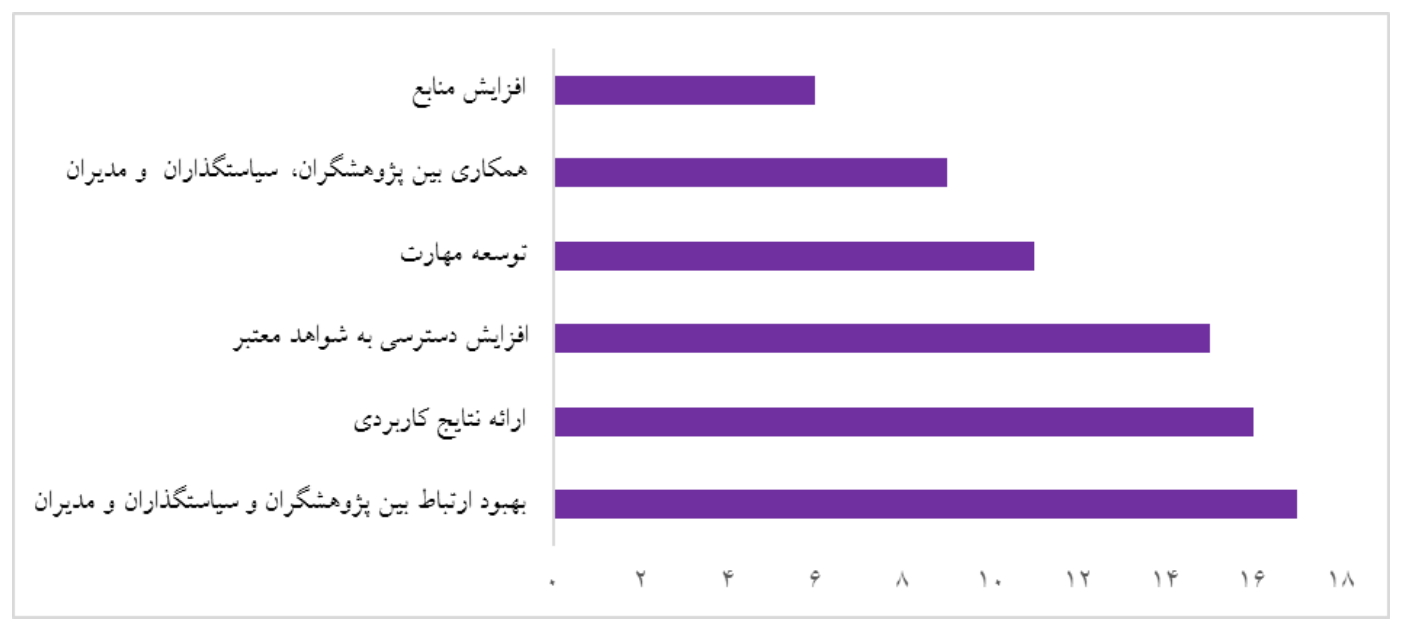

نمودار f: توزيع فراوانى مقالات مورد بررسى بر حسب بيشترين تسهيل كنندههاى ترجمان دانش 
سال بيستم، شماره ينجم، مهر - آبان ...

نشريه يزوهشكده علوم بهداشتى جهاددانشكاهى

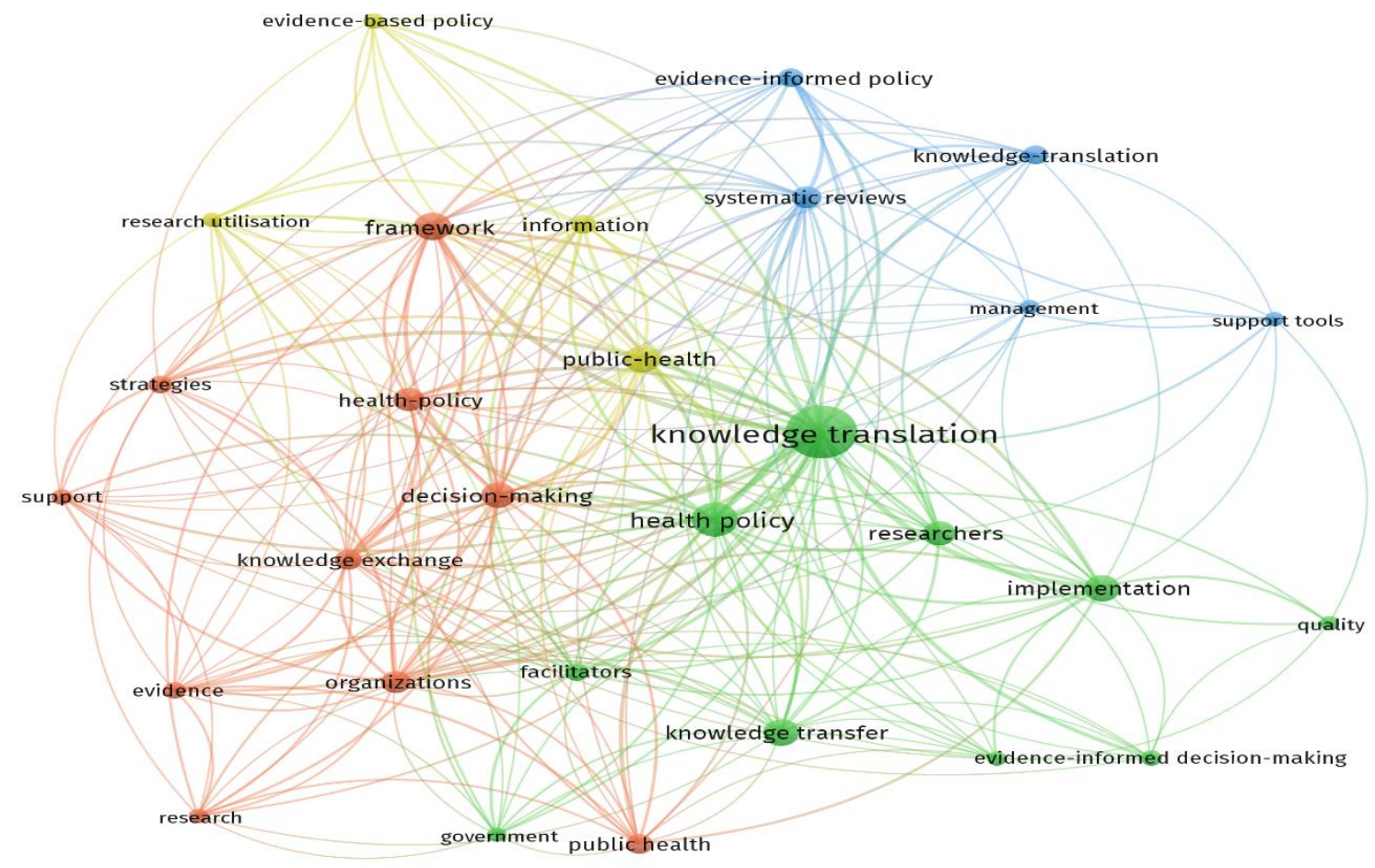

شكل ا: نقشه هم رخدادى وارَّان مورد بررسى در حوزه ترجمان دانش سياستكذارى و مديريت سلامت

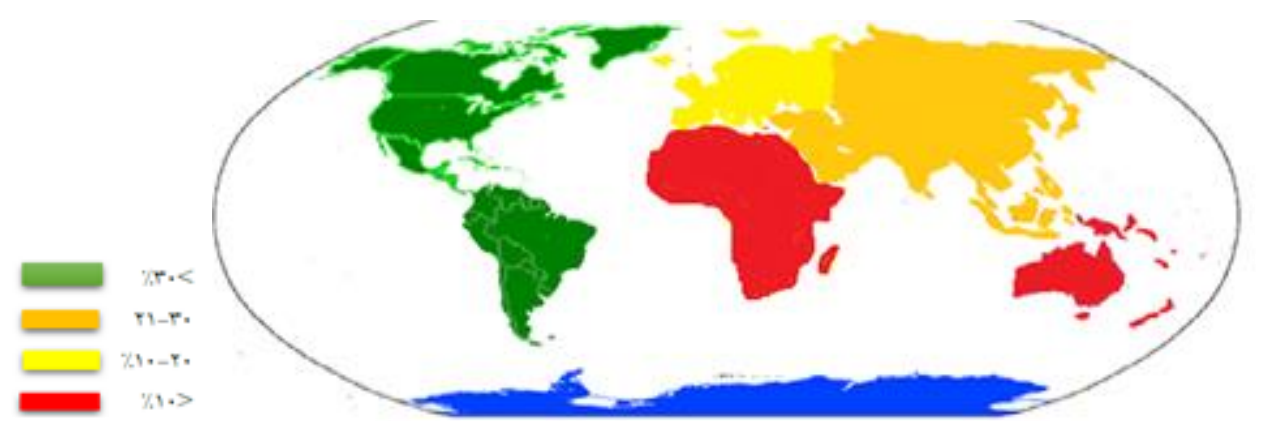

شكل r: توزيع فراوانى درصد مقالات تسهيل كننده هاى ترجمان دانش سياستخذارى و مديريت سلامت در جهان 


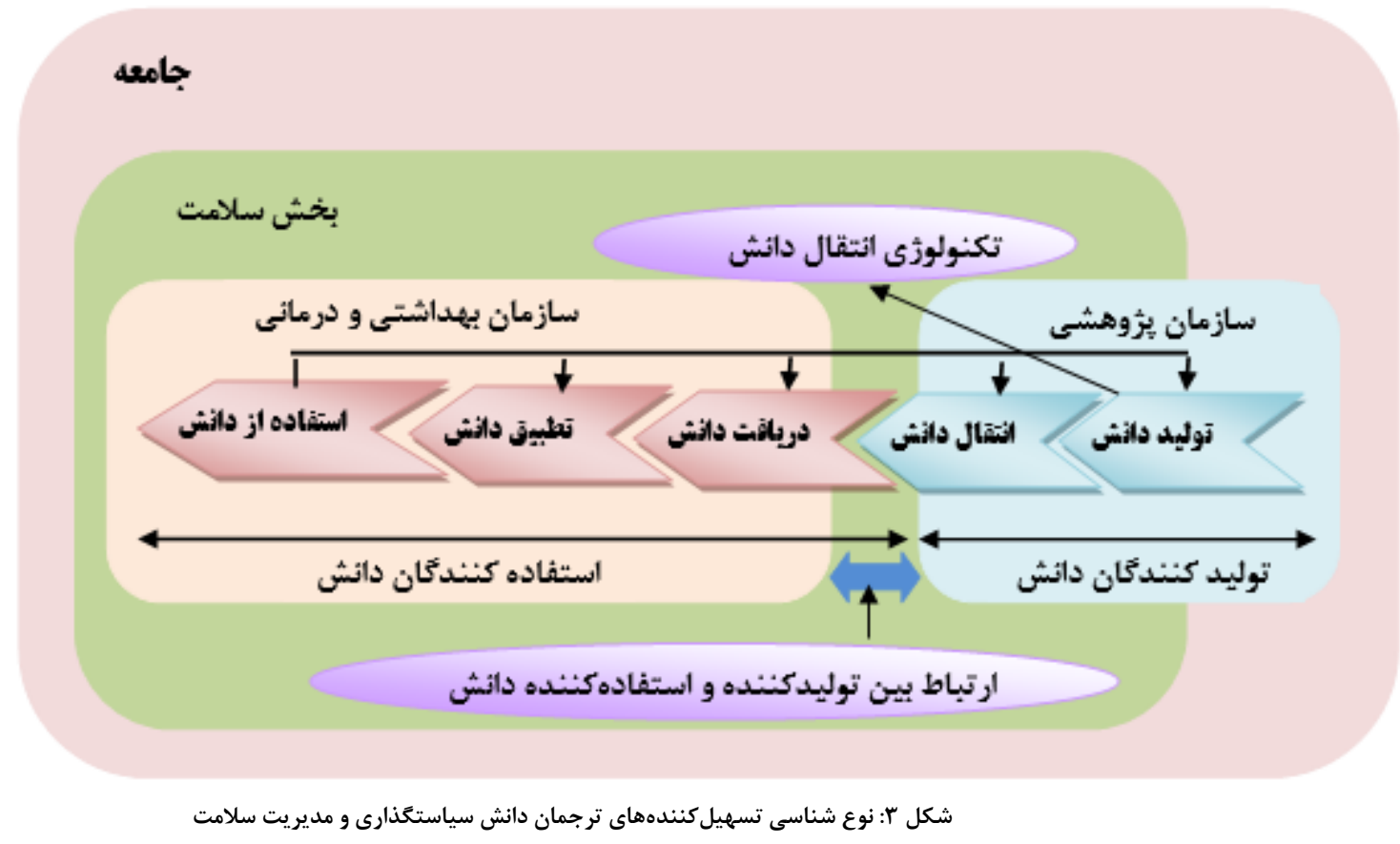

به صـورت خلاصـه و ييشــنهاد سياسـتى، كيفيـت خـوب يـرزوهش،

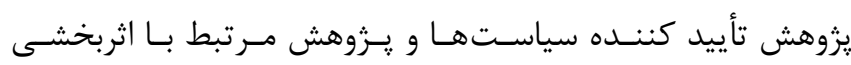
مداخلات [ [1]]. اوليور و همكاران با استفاده از روش مرور نظاممند و

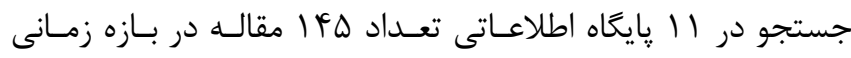

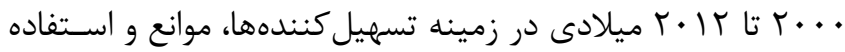

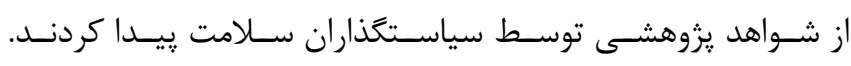
مهمترين تسهيل كنندههاى ترجمان دانش سياستخذارى سلامت در

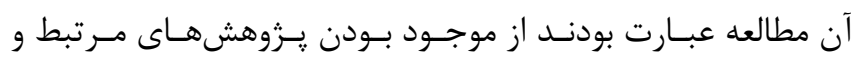

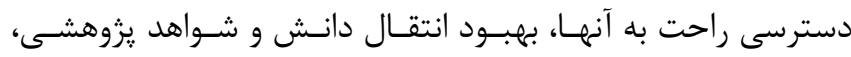

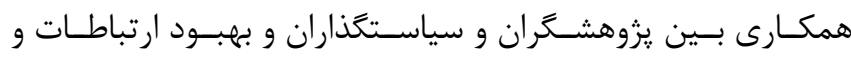

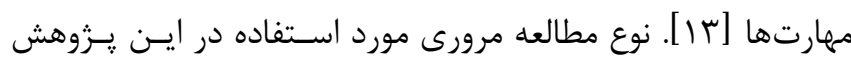

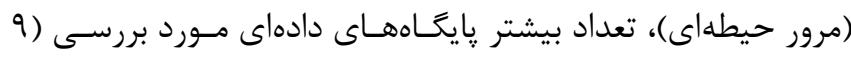

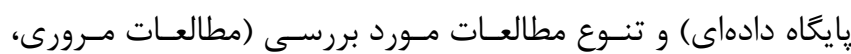
كيفى، كمى و تر كيبى) منجر به شناسايى تسهيل كنندههـاى دانسش بيشترى در اين يزوهش شد. بنابراين، مطالعه مرور حيطهاى ززينسه

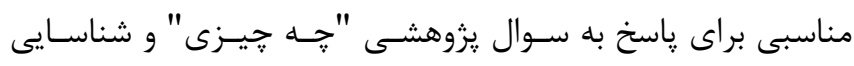

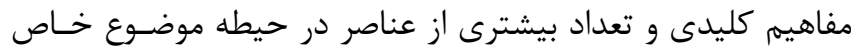

صنعت بهداشت و درمان با عدم اطمينـان بـالايى مواجـه اسـت. در

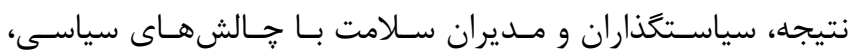

بحث و نتيجه گيرى اين مطالعه با هدف شناسايى تسـهيل كنــدههـاى ترجمـان دانـش سياستخذارى و مديريت سلامت انجام شد. تعداد مطالعات ترجمـان

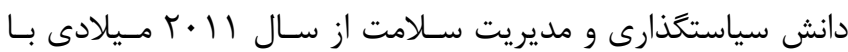

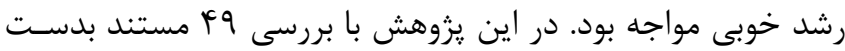

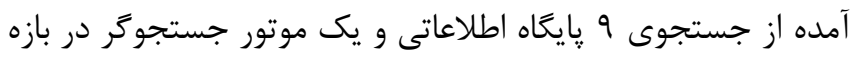

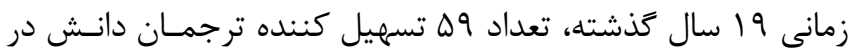

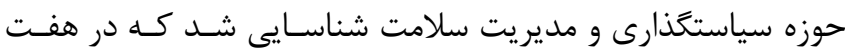

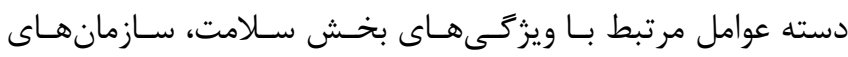
بهداشتى و درمانى، دانش سياستخذارى و مـديريت سـلامت، توليـد

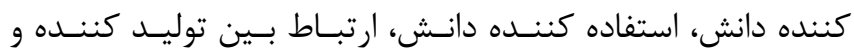
استفاده كننده دانش و فناورى انتقال دانش دستهبندى شد.

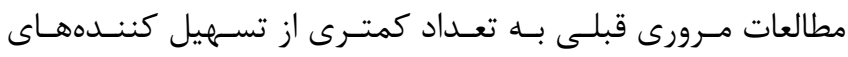

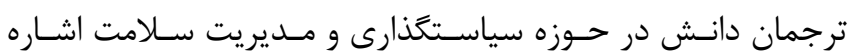

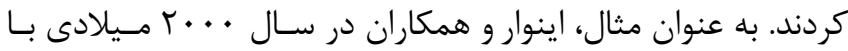

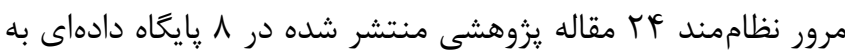

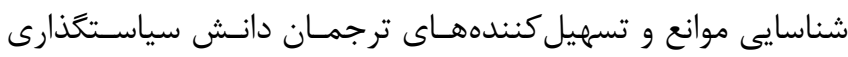
سلامت برداختند. تسهيل كنندههاى ترجمان دانش در ايـن مطالعـه عبارت بودند از تمـاس شخصسى بـين يزوهشــران و سياسـتخذاران سلامت، دسترسى سريع به يافتههاى يزوهشى مرتبط، ارائه يافتههـا 
سازمان، سياستهاى تشويقى تبادل دانش، افزايش مهارت كاركنان،

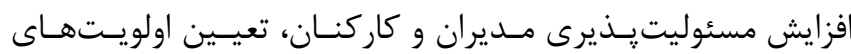

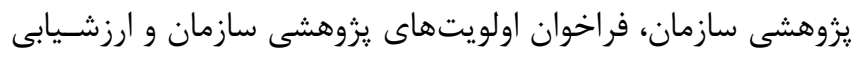

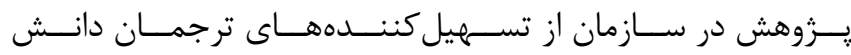

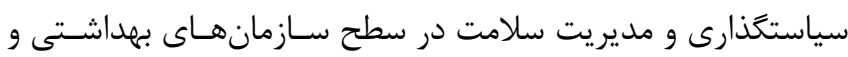

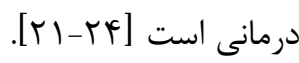
سازمانهاى بهداشتى و درمانى در زمره پيِيحيدهترين سيسـتمهـاى

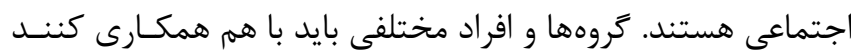

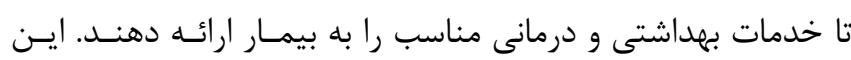

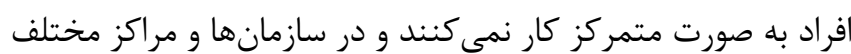
به ارائه خدمت مشغول هستند. اين گروهها و افـراد اطلاعـات بسـيار

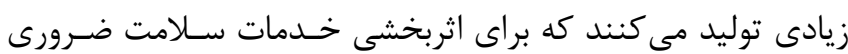

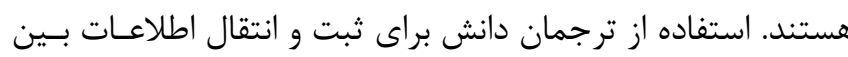

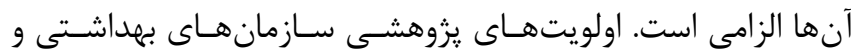

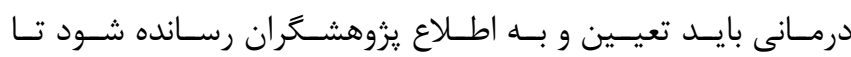

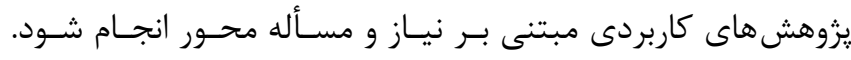

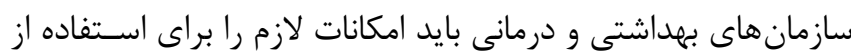
دانش در اختيار مديران قرار دهند. تهيه كتابها و و مجلات تخصصى

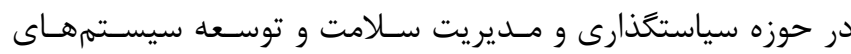

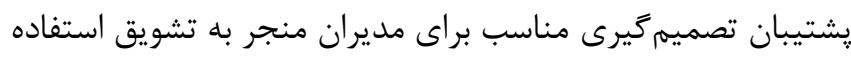

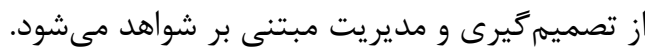

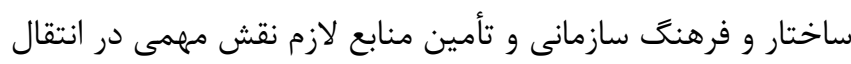

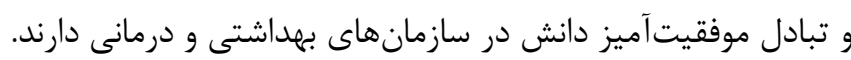
ساختارهاى سازمانى مناسب بايد براى تسهيل ترجمان دانش ايجـاد

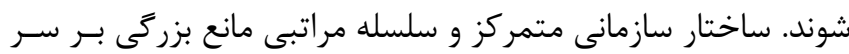

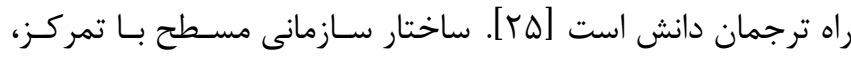

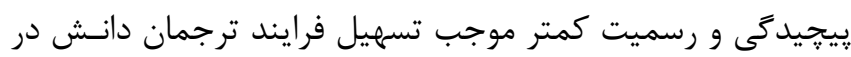

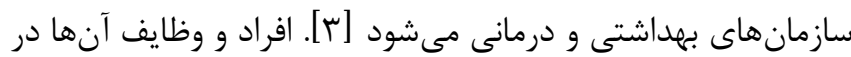

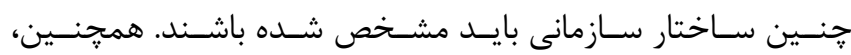

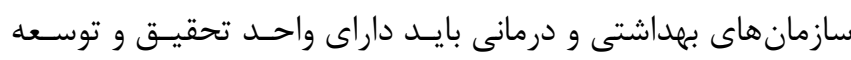

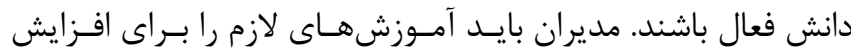

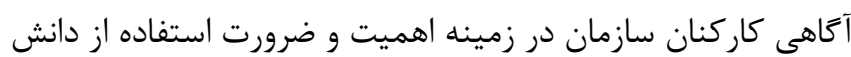
در عمل فراهم كنند و منابع لازم را براى جذب، تطبيق و استفان إناده از

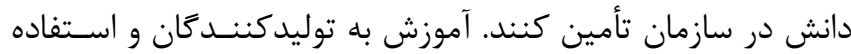

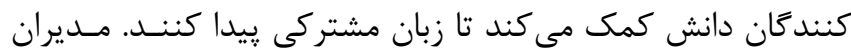

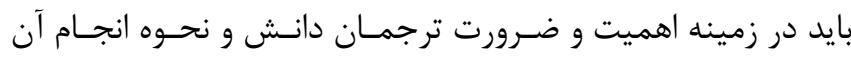

اقتصادى و اجتماعى فراوانى مواجه هستند. دانش مـورد نيـاز بـراى رفع קالشهاى نظام سلامت يراكنده بوده و از منابع مختلفى بدست

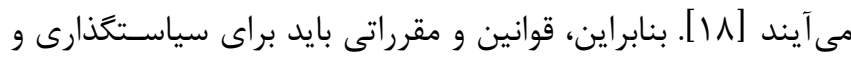

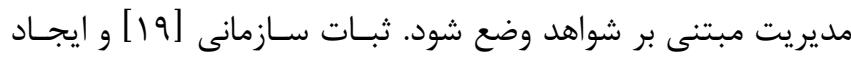

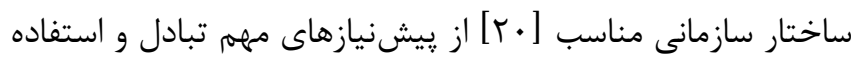

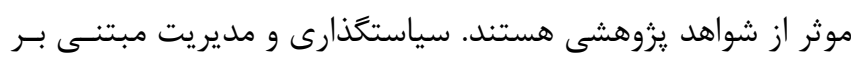

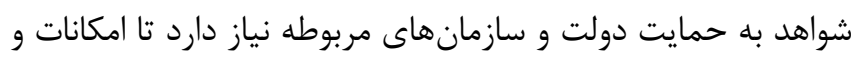
منابع لازم براى انجام يزوهشهاى كاربردى، انتقال نتايج يـرؤهش و و

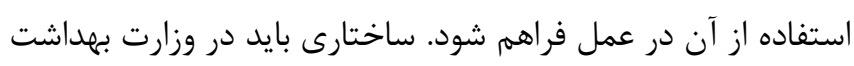

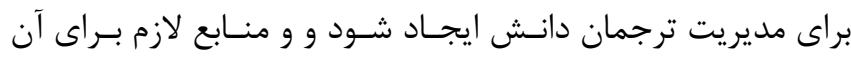

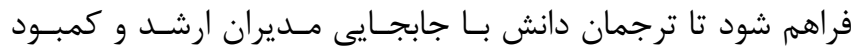

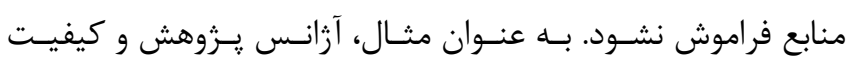

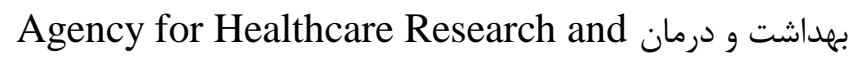
Quality در آمريكا، سازمان موسسـات يـزوهش سـلامت كانـادا ،The Canadian Institutes for Health Research National Institute for مؤسسـه ملـى مطالعـات بـالينى

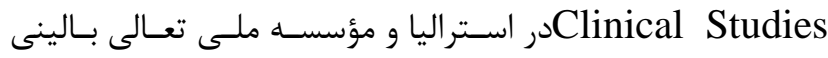
در National Institute for Clinical Excellence

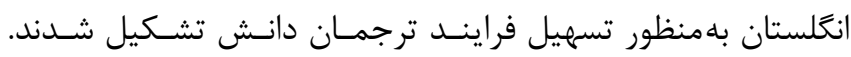

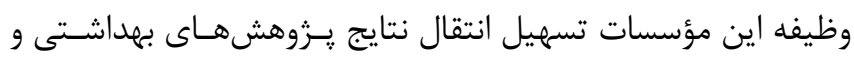

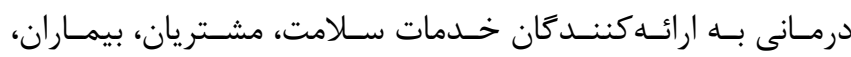

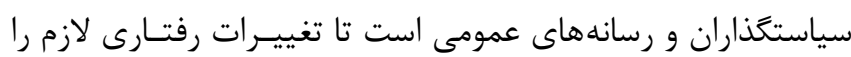

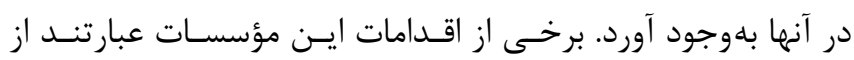

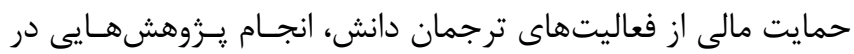

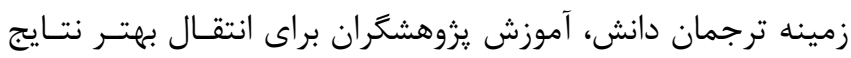

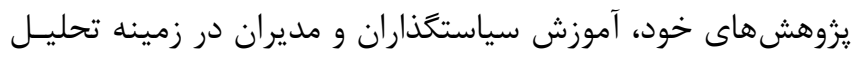

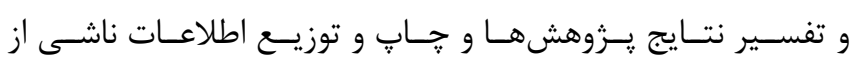

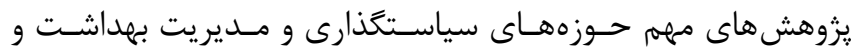

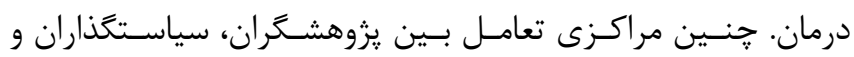

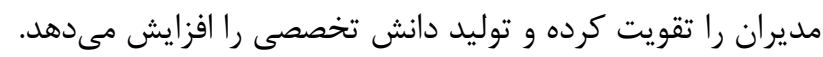

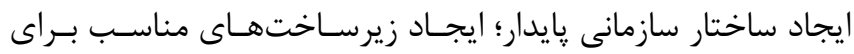

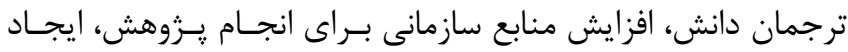

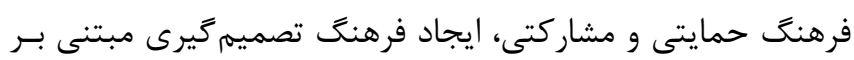

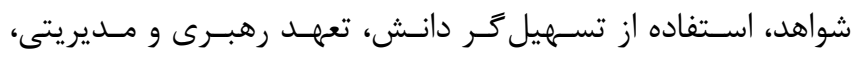

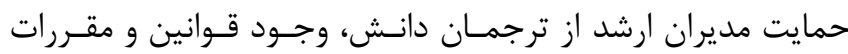

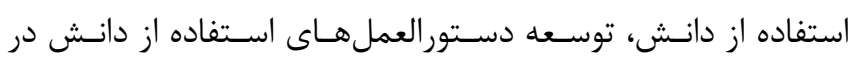




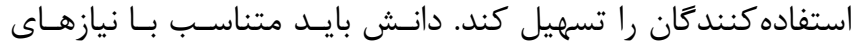

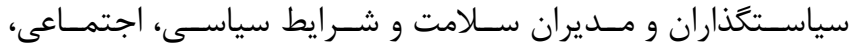

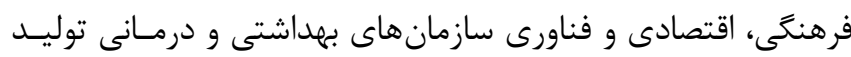

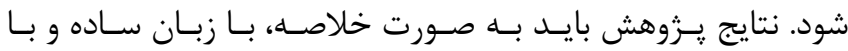

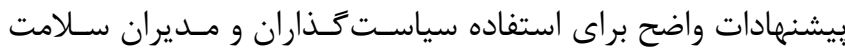

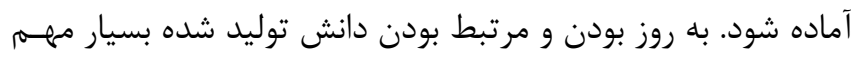

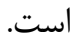

سياستخذاران و مديران بيشتر از يزوهش (دانش تصريحى) به تجربه

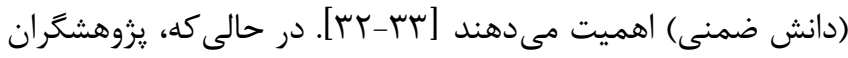

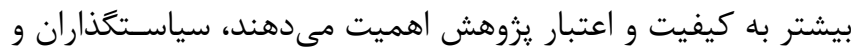

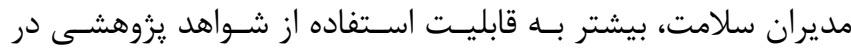

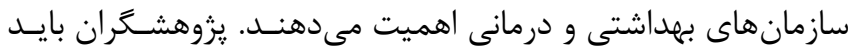

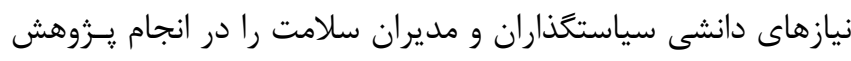

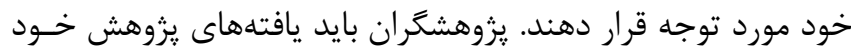

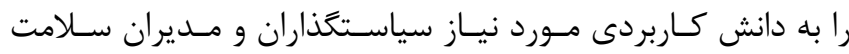

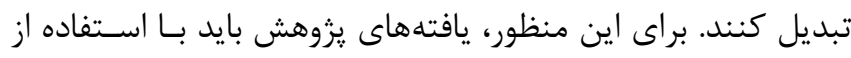

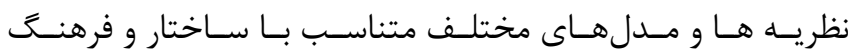
سازمانهاى بهداشتى و درمانى تكامل يابند.

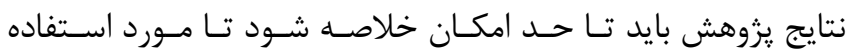

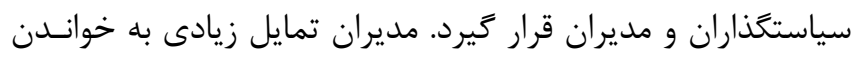

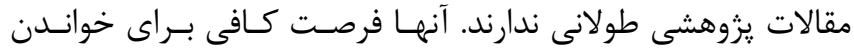

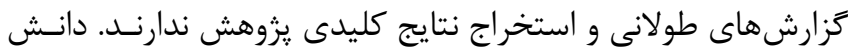
جديد بهتر است با كمك ابزارهايى نظير خلاصه سياستى

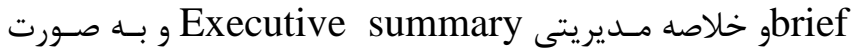
مفيد و مختصر در اختيار سياستخذاران و مديران سلامت قرار گيرد.

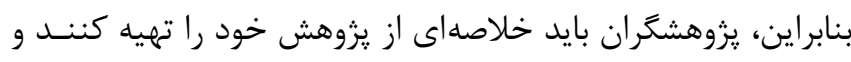

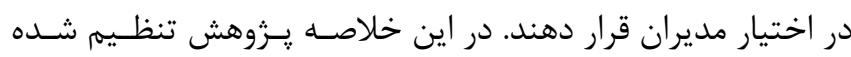

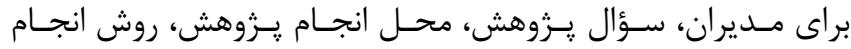

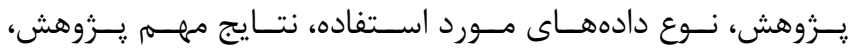

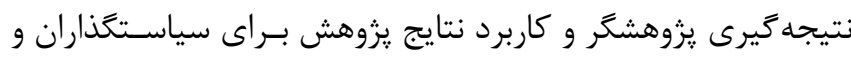
مديران سلامت بايد ذكر شود. ساختار مجلات تخصصى سياستخذارى و مديريت بهداشت و درمـان

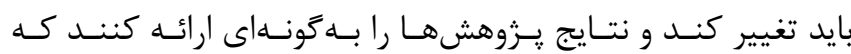

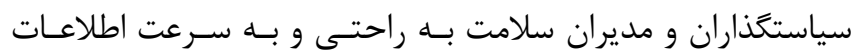

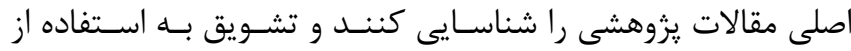

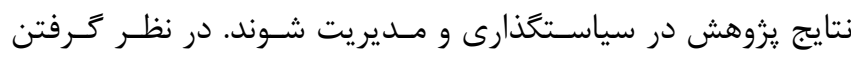

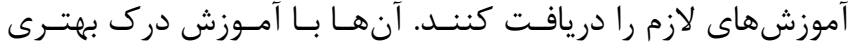

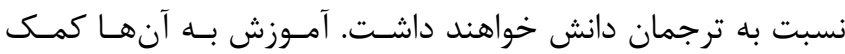

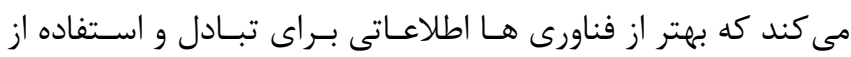

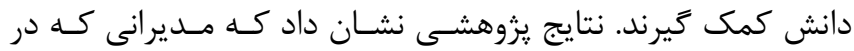

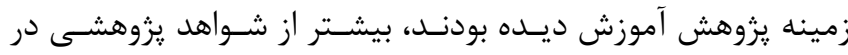

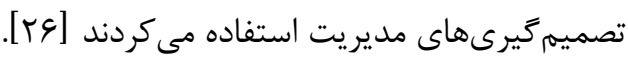

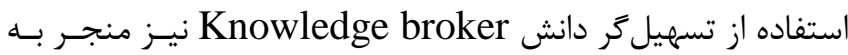
تسهيل فرايند ترجمان دانش در سازمان مىشود. تسهيل

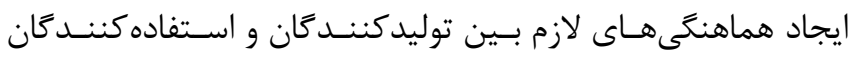

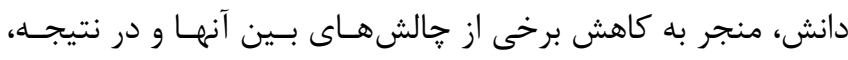

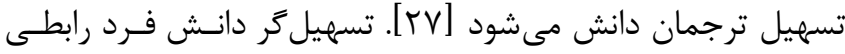

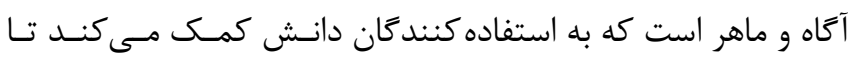

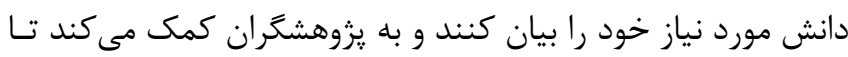
آن دانش را توليد كنند. تسهيل

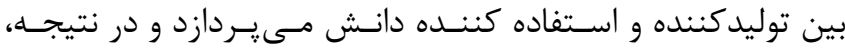

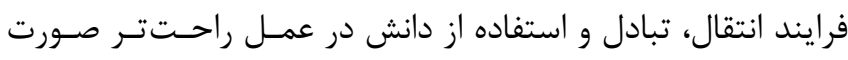

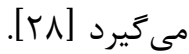
فرهنَ سازمانى بايد حامى ترجمان دانش باشد. فرهنـَ سـازمانى

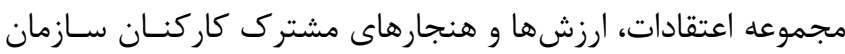

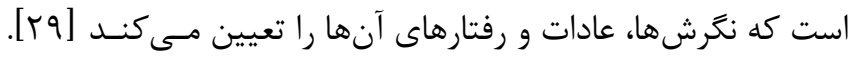
حمايت و يشتيبانى مديران ارشد نقش مهمى در موفقيـت ترجمان

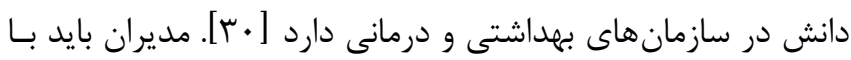

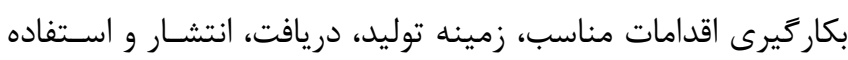
درست از دانش كاربردى را بين بخش هاى مختلـف سـازمان فـراهم كنند. مديران بايد ظرفيت مديريت دانش سازمان را توسعه دهند. از

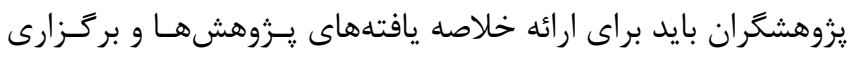

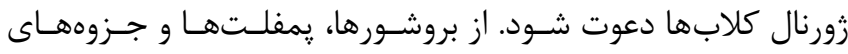

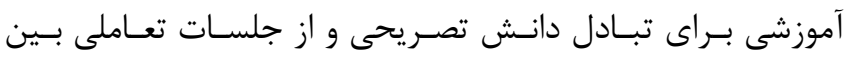

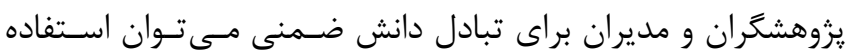

سياستخذاران و مديران بهداشتى و درمانى براى تصميمگيـرىهـاى

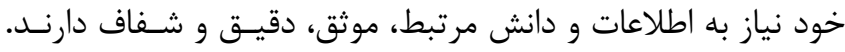

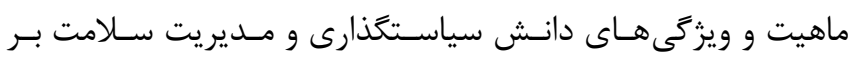

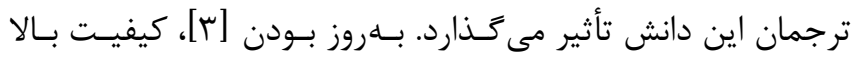

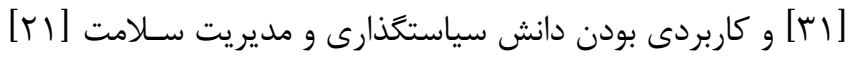

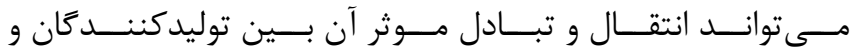


سياستخذاران و مديران در انجام يزوهش، افزايش كيفيت يـرؤهش و

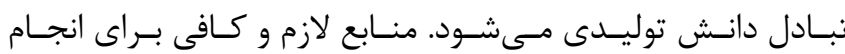

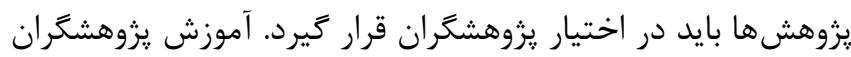

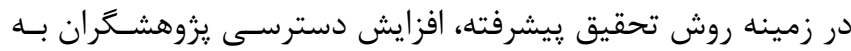

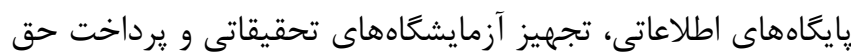

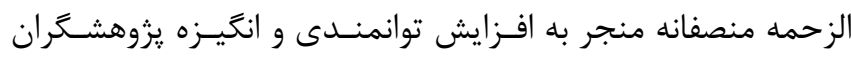
براى ترجمان دانش مىشود.

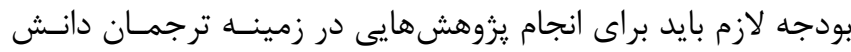

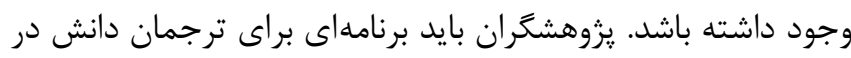

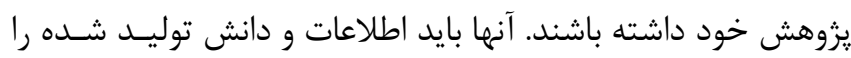

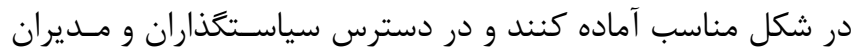

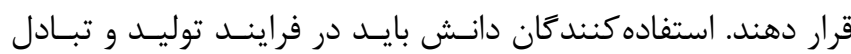

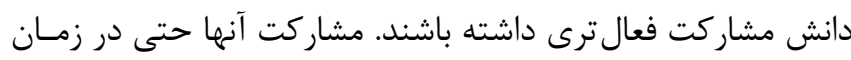

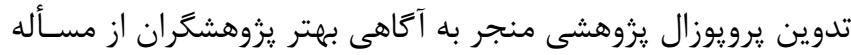

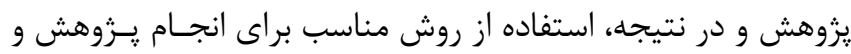

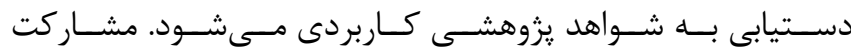
سياستخذاران و مديران سلامت در تعيين سـوال يـرزوهش، انتخـاب

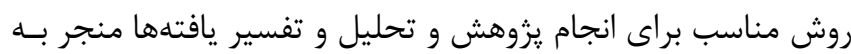
افزايش انكَيزه آنها براى استفاده از دانش توليد شده مى شودود.

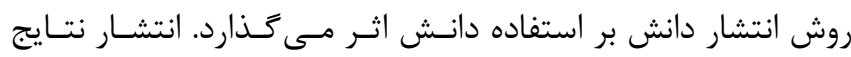

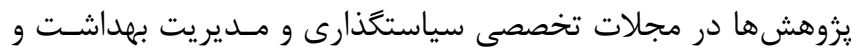

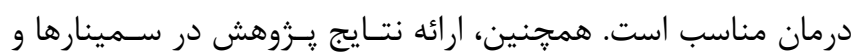

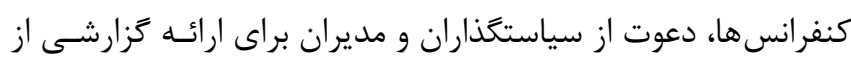
يزوهش، نمايش نتايج يزوهشها در وب سايتهاى تخصصى، انتشار در مجلات معتبر ير خواننده، ارسال تزارشات يا مقالات حاصله برائ براى

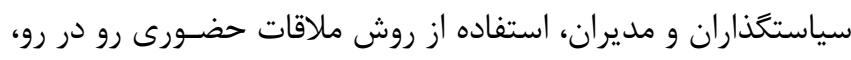

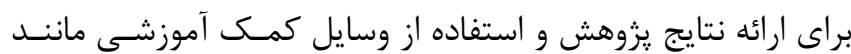

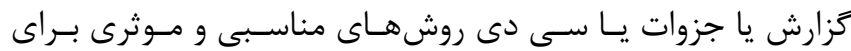
انتقال شواهد يزوهشى هستند.

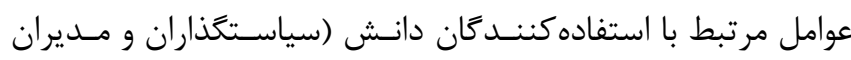
سلامت) نيز بر اثربخشى فرايند ترجمان دانش اثر مى كذارد. آموزش الثران

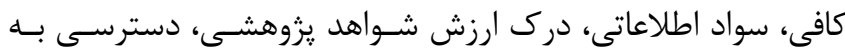

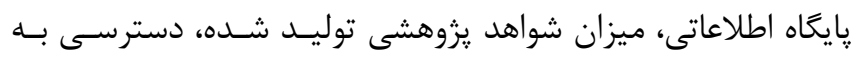

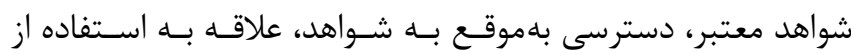
يزوهش، داشتن وقت كافى براى استفاده از دانش و مهـارت ارزيـابى إنى

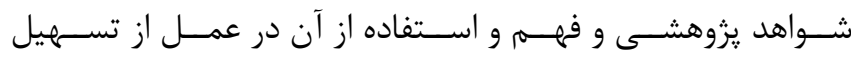

قســمتهـايى نظيـر "كـاربرد نتــايج در سياسـتَكذارى و مــديريت

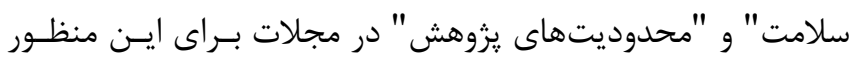

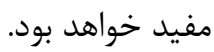

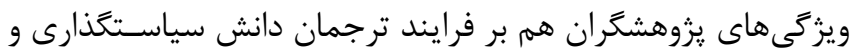

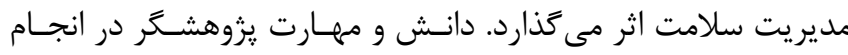

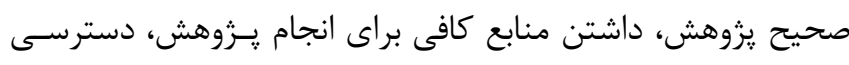

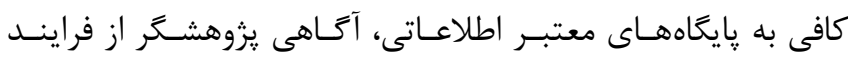

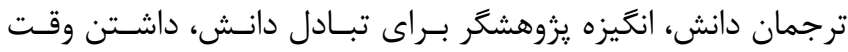

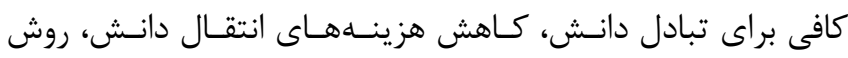

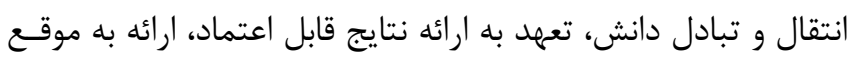

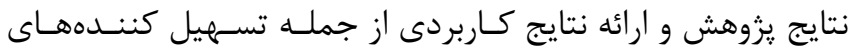

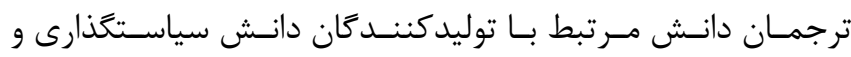

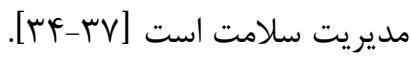

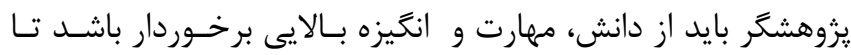

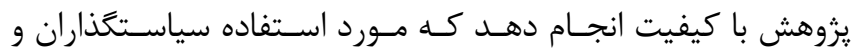

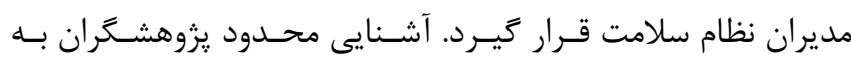

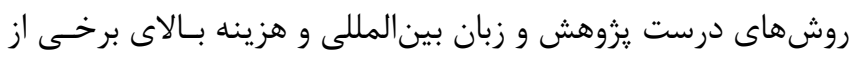

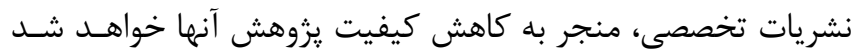

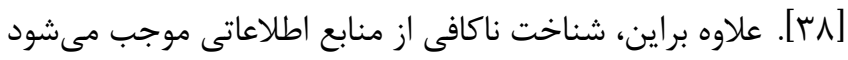

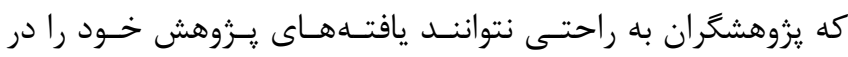

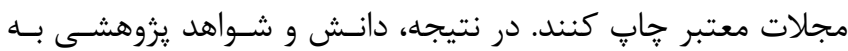
موقع به دست استفاده كنند

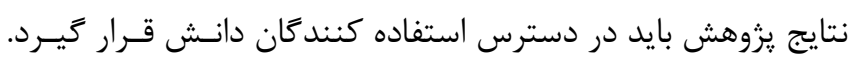
يزوهشكران بايد نقش فعالترى در ترجمان دانش داشته باشند. آنهـا

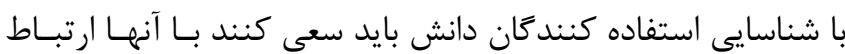

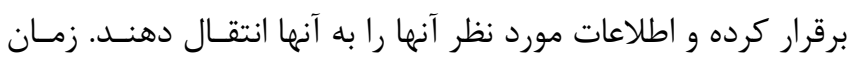

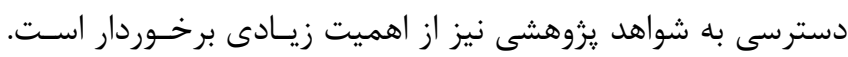

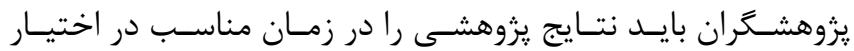

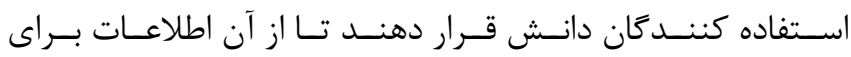

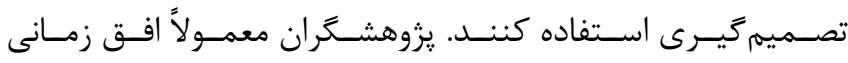

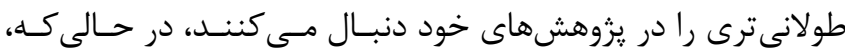

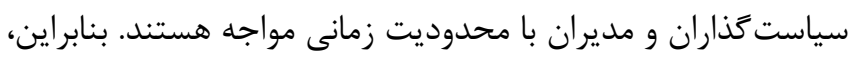

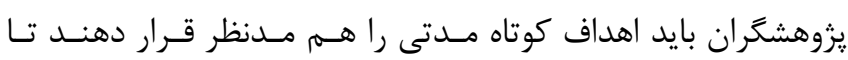

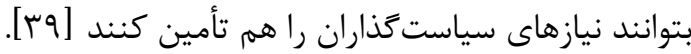
ميزان حق الزحمه كم يزوهشكران نسبت به زمانى كه صـرف انجـام

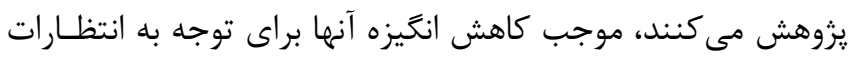


انجام پايان نامه است. در نتيجه، آنها با فراينــد يـرُوهش و ترجمـان دانش بيشتر آشنا خواهند شد.

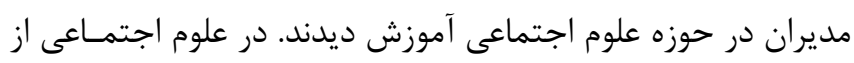

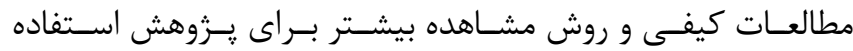

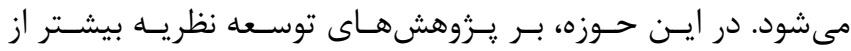

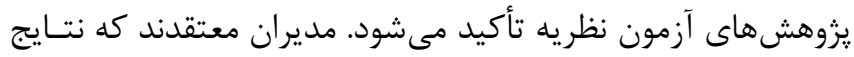
يزوهش ها متناسب با نوع سازمان متفاوت است. فرايند تصميم كيرى مديران فرايند يِيجيدهاى است. مديران تصميمات كم، ولى بزركترى

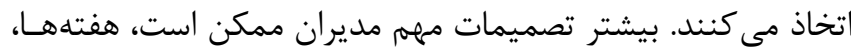

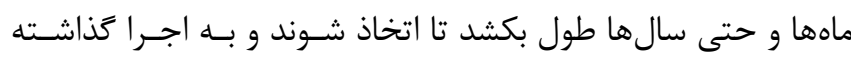

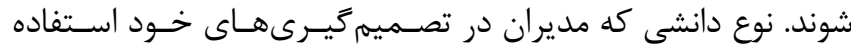

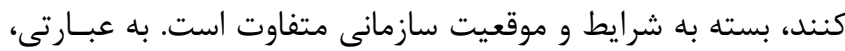

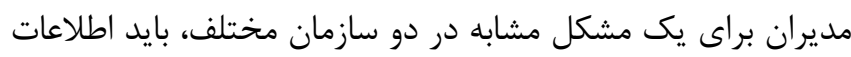

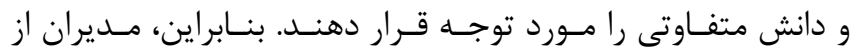
راهنماها و سيستمهاى يشتيبان تصميمَيرى مرسوم در حوزهــاى

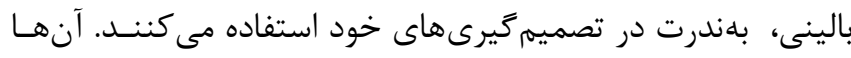

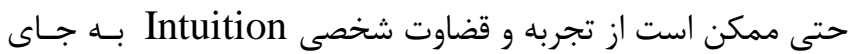

شواهد علمى يزوهشى استفاده كنند [FF]

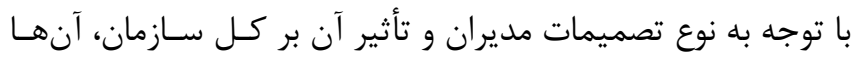

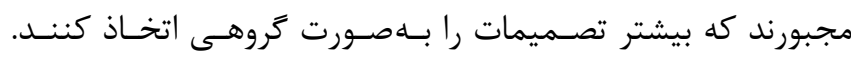

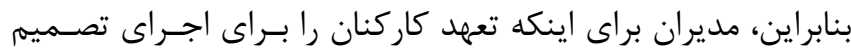

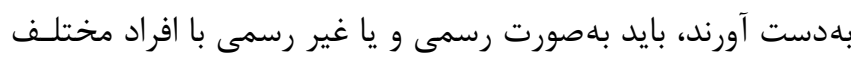

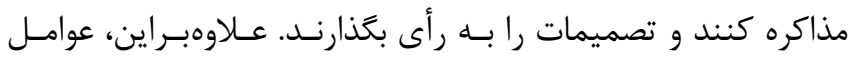

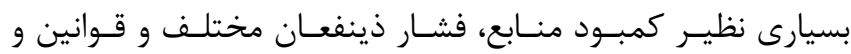

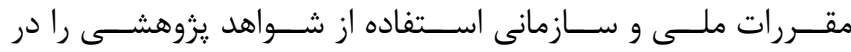

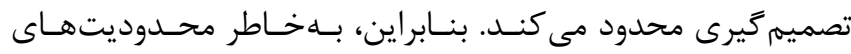

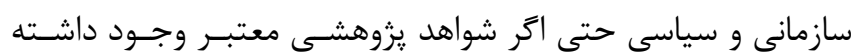

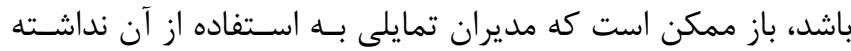

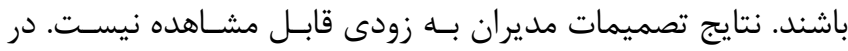

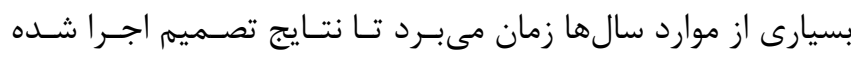

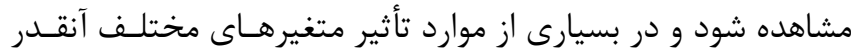

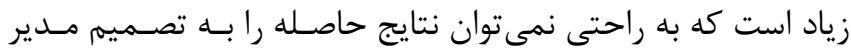

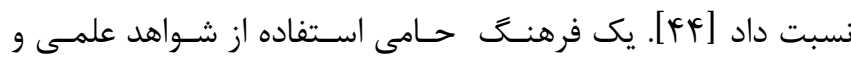

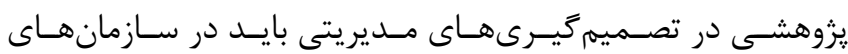

$$
\text { بهداشتى و درمانى تقويت شود. }
$$

كنندهاى مرتبط با استفاده كنندگان ترجمان دانش سياستگذارى و

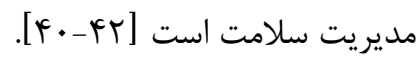

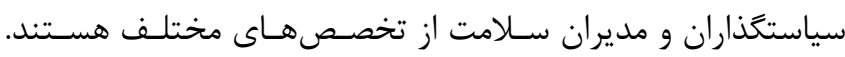

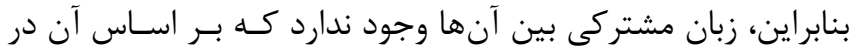

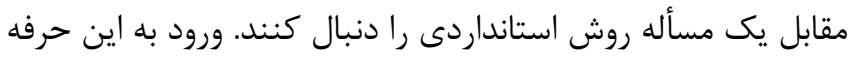

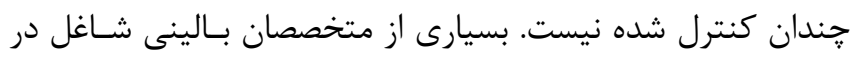

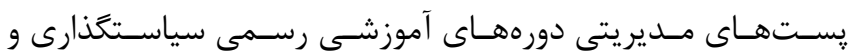

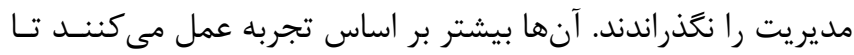

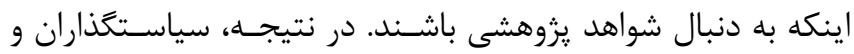

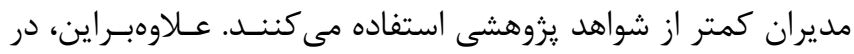

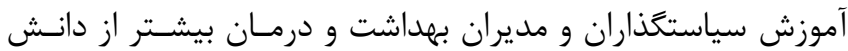
تصريحى، بر دانش ضمنى تأكيد مىشود.

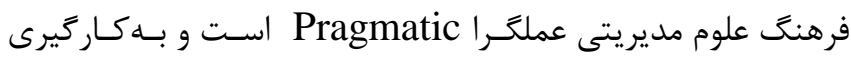

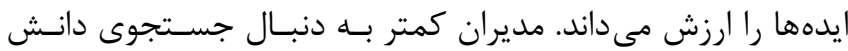

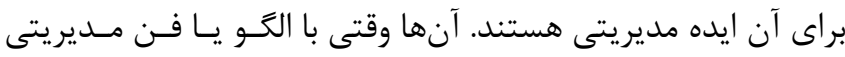

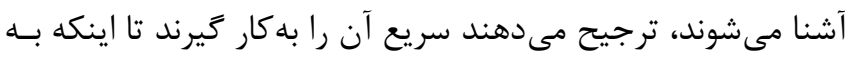
جستجوى سوابق علمى و يزوهشى آن برآيند. مديران خيلى سـى سـريع

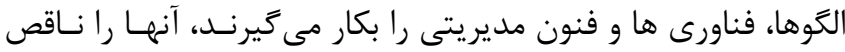

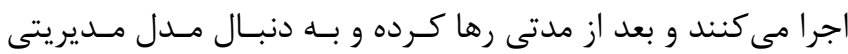

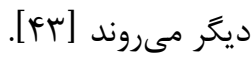

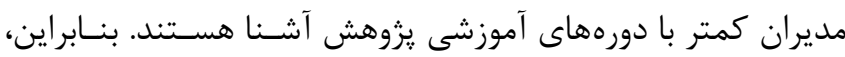

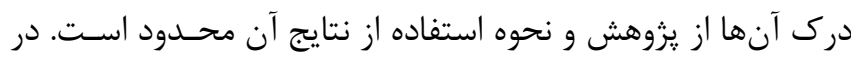

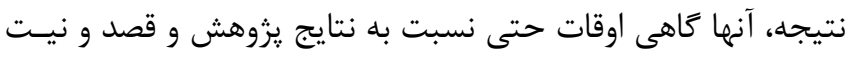

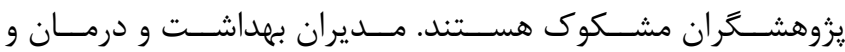

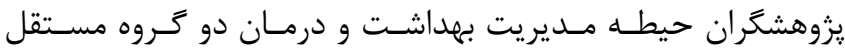

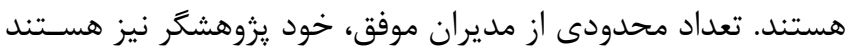

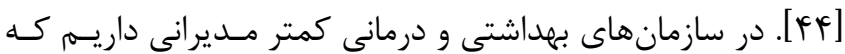

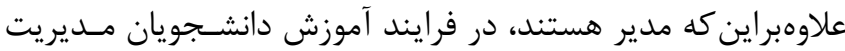

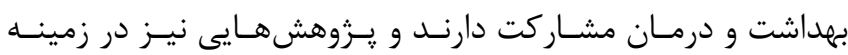

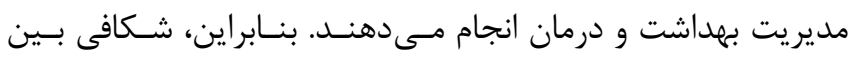

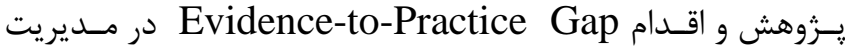
بهداشت و درمان وجـود دارد. توسـعه مـديريت مبتنسى بـر شـواهد

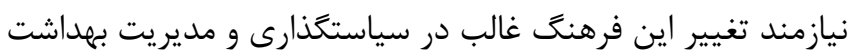

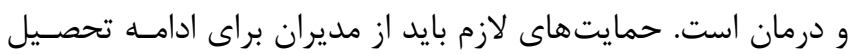

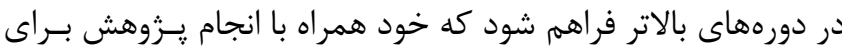




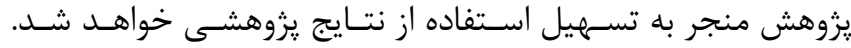

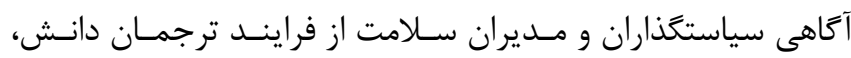

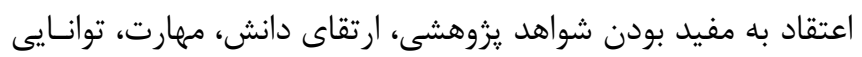

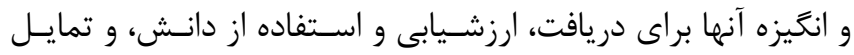

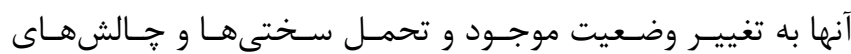

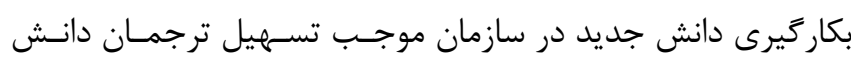
سياستخذارى و مديريت سلامت مىشود.

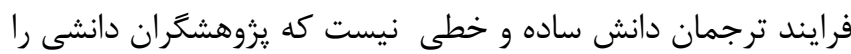

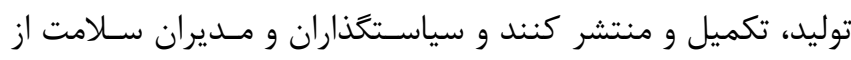

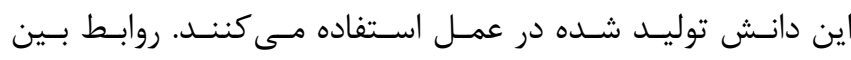

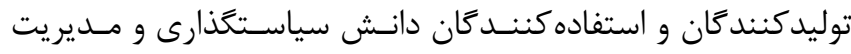

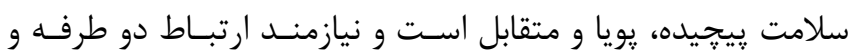

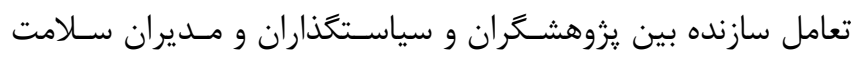

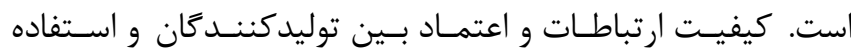

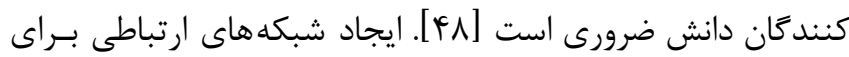

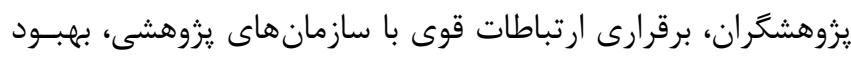

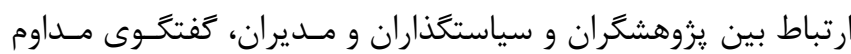

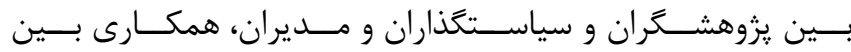

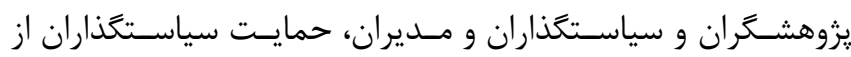

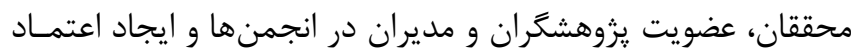

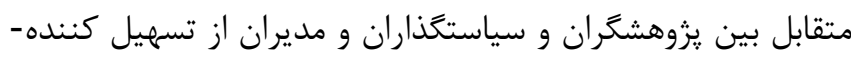

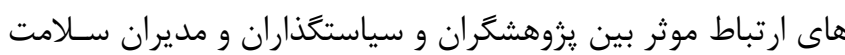

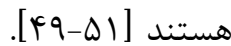

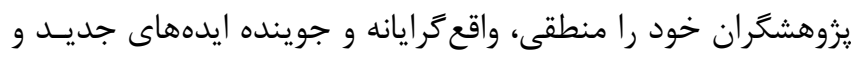

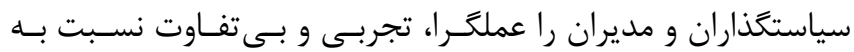

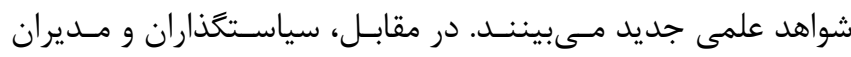

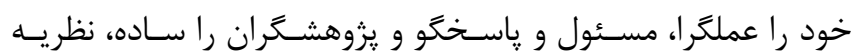
يرداز و بى تفاوت نسبت به واقعيتهاى عملسى مسىبينــد. بنـابراين،

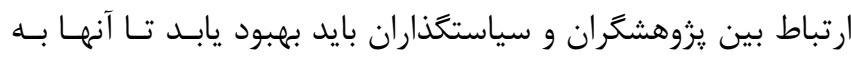

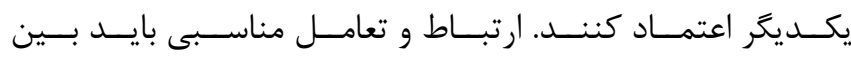
توليدكنند نياز سياستخذاران و مديران به صورت كـاربردى توليـد و در نهايـته

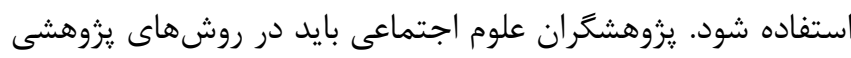

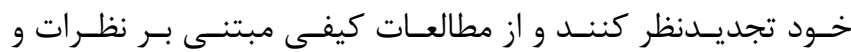

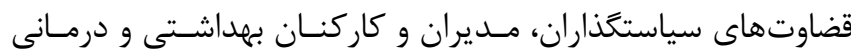
استفاده كنند تا جنبههاى كاربردى دانش توليد شده تقويت شود.

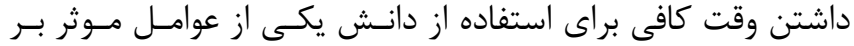

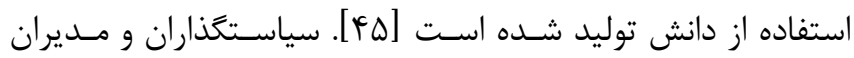

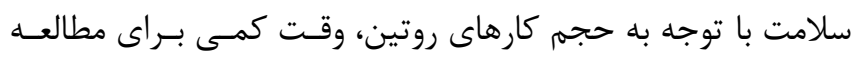

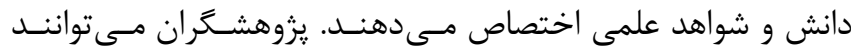

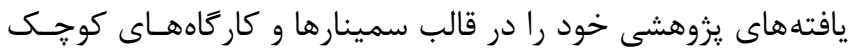

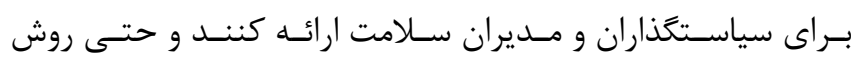

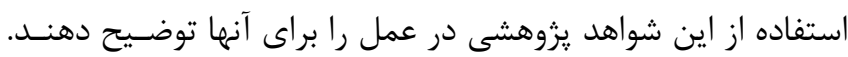

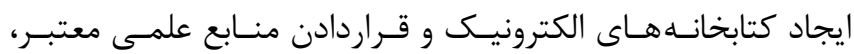

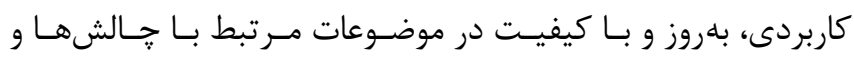
مشكلات سياستكذاران و مديران سلامت در اين زمينه مفيد است. افزايش دسترسى به شواهد يزوهشى منجر به تسهيل ترجمان دانش

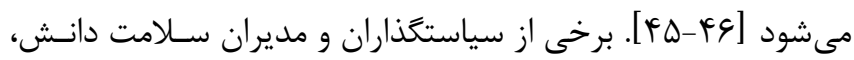

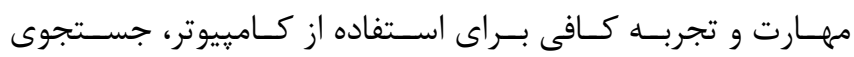

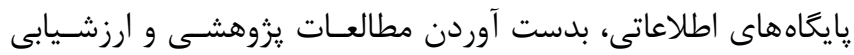

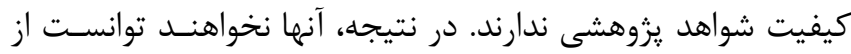

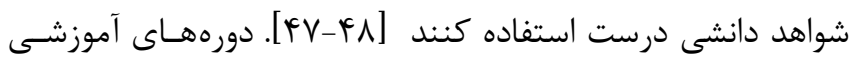

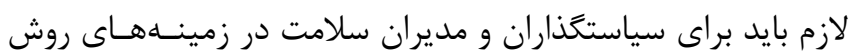

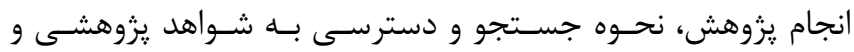

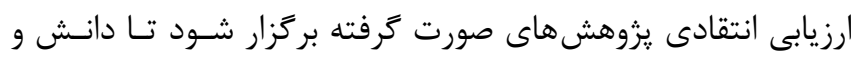

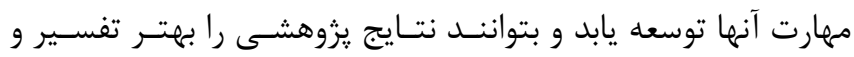

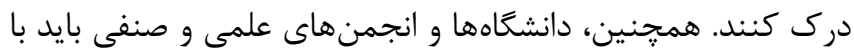

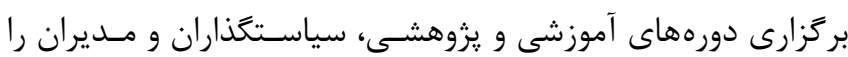

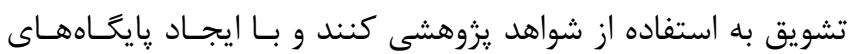

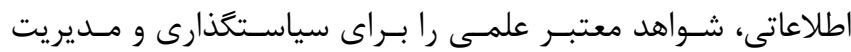

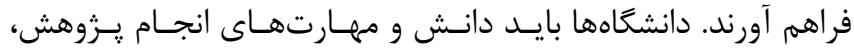

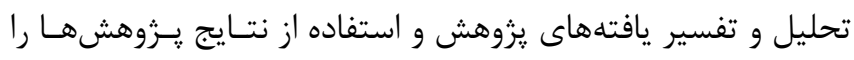

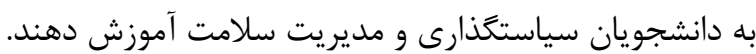

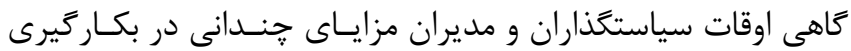

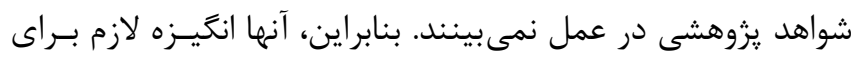

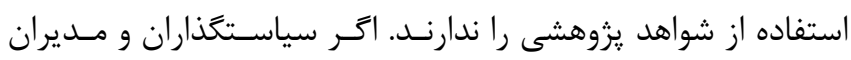

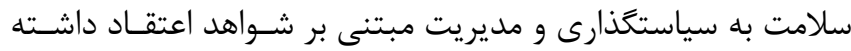

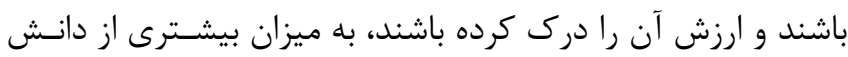

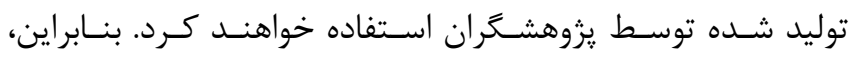
مديران بايد از مزاياى شواهد يزوهشى مطالع و تشويق شـوند تـا در

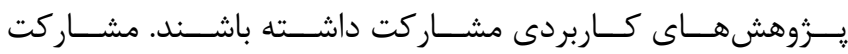

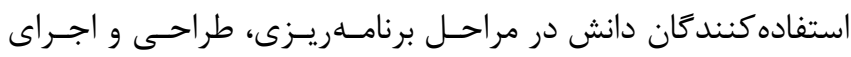


مى شود كه يزوهش هاى مرتبط با نيازهاى استفاده كنندكان انجـام

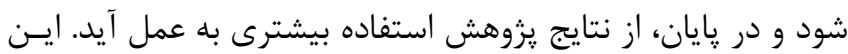

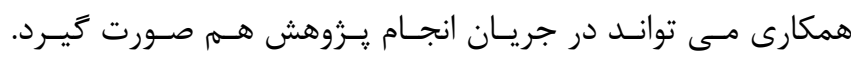
همكارى استفاده كنند

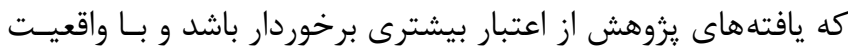

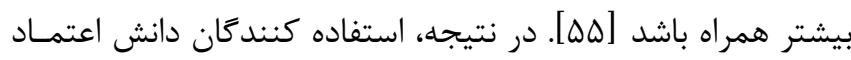
بيشترى به يافته هاى يزوهش خواهند داشت. بـاهن دانشخاهها و موسسات آموزشى بايد ظرفيـت لازم را بـراى ترجمـان

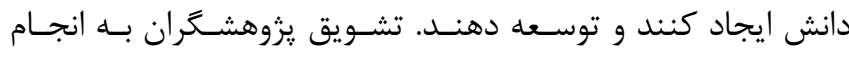

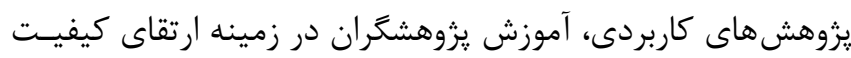
يزوهش، تشويق مشاركت سياستخذاران و مديران سلامت در فرايند يروهش، ايجاد ساختارى براى تسهيل فرايند ترجمان دانش، تبـديل

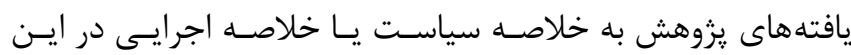

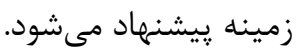

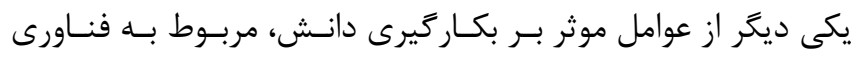

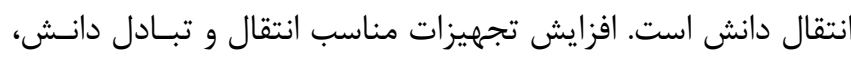

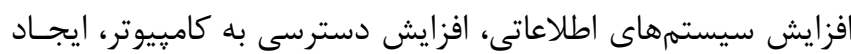

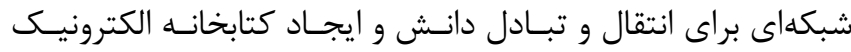
منجر به تسهيل ترجمان دانـش سياسـتخذارى و مـديريت سـلامت

مىشود [سץ، 19.

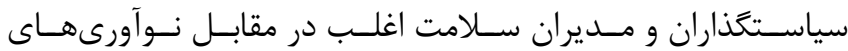
كامييوترى مقاومت مى كنند. آنها به ويزه هنگَامى كه اين فراينـدها در بر ₹يرنده مقدار زيادى از دانش ضمنى هم باشد، فكر مى كنند كه

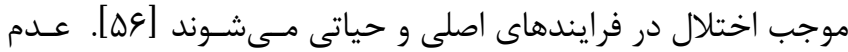

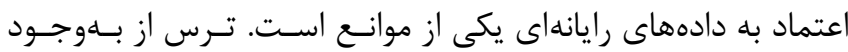

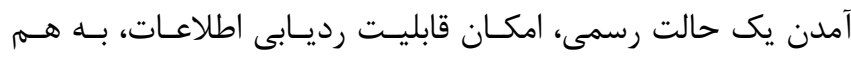

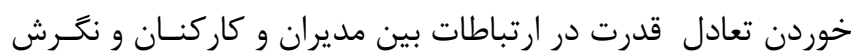

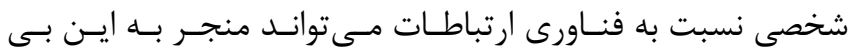

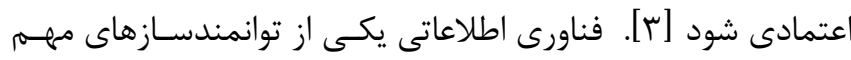

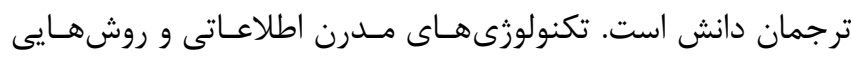
مانند داده كاوى به سياستخذاران و مديران سلامت كمك مى كند تا اطلاعات و دانش مورد نياز را سريع دريافت كنند. علاوه براين، ايجاد كتابخانهای الكترونيكى نقش بسزايى در دسترسى سياسـتخذاران و و

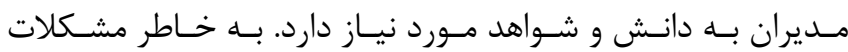

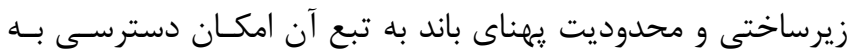

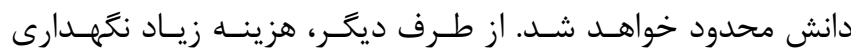

انتقــال و تبــادل دانـش نيازمنــد بــهـ ارتباطــات و همكــارى بــين

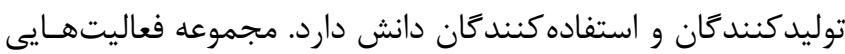

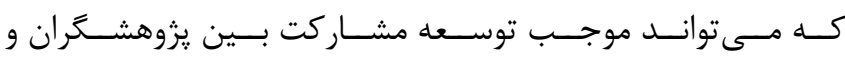

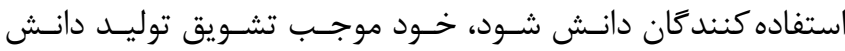
مرتبط، به روز، و كاربردى براى استفاده كنندكان دانش مىشود. هـر

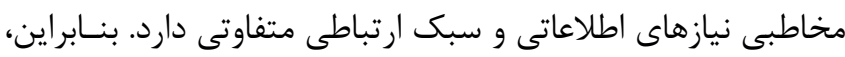

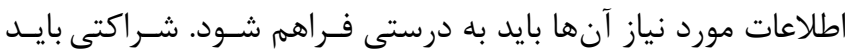
بــين توليدكنـــــان و اسـتفاده كنـــــان دانـش (سياسـتخذاران و مديران سلامت) ايجاد شود تا آنها بهتر بتوانند به نيازها و انتظـارات

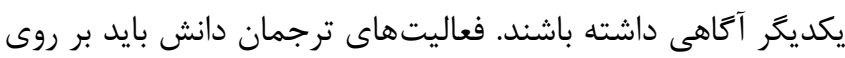

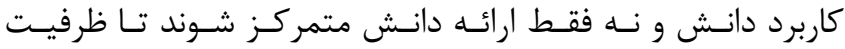
استفاده كننده دانش را براى تفسير دانسش و اسـتفاده از آن افـزايش

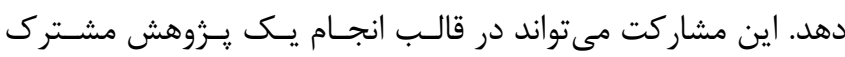
توسط توليدكننده و استفاده كننده دانش صورت كيرد.

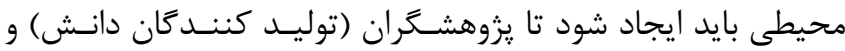
سياستخذاران و مديران (استفاده كنند هم در جلسهاى شركت كنند و نظرات و انتظارات خود را بيان كنند. جوى بايد ايجاد شود تا منجر به توليد و تبادل دانش كاربردى بـين

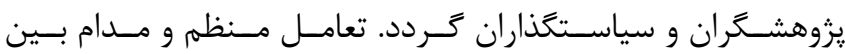

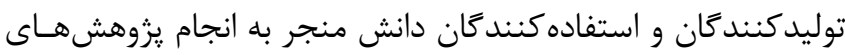
مناسب توسط يزوهشگران و ترجمه آسان و صحيح آن براى استفاده سياستخذاران و مديران مىشود. برقرارى شـرايط كفتخَـوى سـازنده

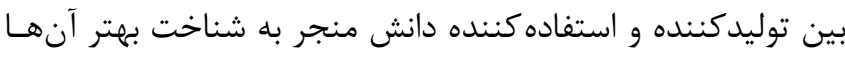

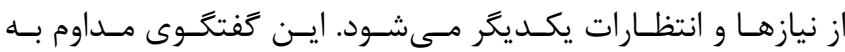

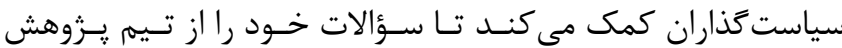
بيرسند و در صورت نياز مهارتها و ابزارهاى لازم را بهدست آورند تا بـان

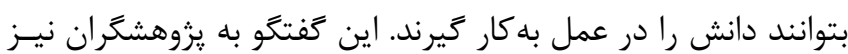

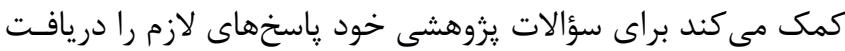

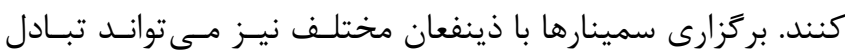

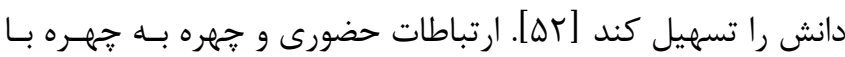

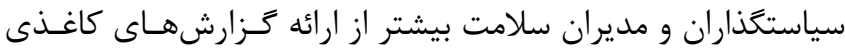

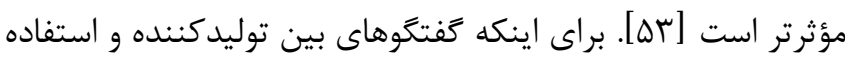
كنند Fان دانش به نتيجه برسد بايد دو طرف متعهد به انجام صحيح ترجمان و تبادل دانش شوند. همكارى بين يروهشگران و استفاده كنند

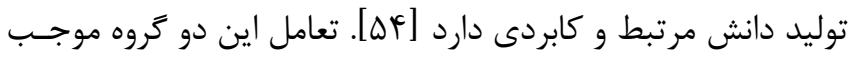


دانـش سياسـتخذارى و مــديريت سـلامت شناسـايى شـده در ايـن يزوهش، به كمّى سازى تسهيل كنـندهاى ترجمان دانسش در حـوزه

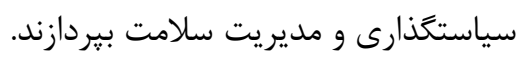

\section{سهم نويسند}

على محمد مصدقر اد: طراحى يزوهش، جمـع آورى دادههـا، تحليـل دادهها و نغارش مقاله يروانه اصفهانى: جمع آورى دادهها، تحليل دادهها و نغارش مقار مقاله

\section{تشكر و قدردانى}

اين مقاله حاصل بخشى از طرح تحقيقاتى با عنوان "موانع ترجمـان دانش در سازمان هاى بهداشتى و درمانى" بود كه با حمايت دانشعاه

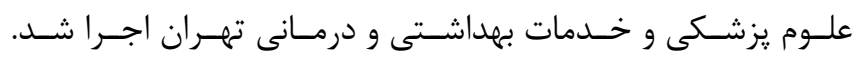
نويسند كيفيت اين مقاله كمك كردند، كمال تشكر و قدردانى را دارند.

\section{منابع}

1. Kudyba SP. Healthcare informatics: improving efficiency and productivity. $1^{\text {st }}$ Edition, USA: CRC Press; Taylor \& Francis Group 2010

2. Canadian Institutes of Health Research. Knowledge Translation - Definition 2021 [Available from: http://www.cihr-irsc.gc.ca/e/29418.html.]

3. Mosadeghrad AM, Isfahani P. Barriers to Knowledge Translation in Health Policy and Management: A Scoping Review. Hakim Research Journal 2020; 23:86-103 [In Persian]

4. Pablos-Mendez A, Shademani R. Knowledge translation in global health. Journal of Continuing Education in the Health Professions 2006; 26:81-6

5. Brownson RC, Eyler AA, Harris JK, Moore JB, Tabak RG. Research full report: getting the word out: new approaches for disseminating public health science. Journal of Public Health Management and Practice 2018; 24:102

6. Jernberg T, Johanson P, Held C, Svennblad B, Lindback $\mathrm{J}$, Wallentin L. Association between adoption of evidence-based treatment and survival for patients with ST-elevation myocardial infarction. JAMA 2011; 305:1677-84

7. Davis D, Evans M, Jadad A, Perrier L, Rath D, Ryan D, et al. The case for knowledge translation: shortening the journey from evidence to effect. BMJ 2003; 327:33-5

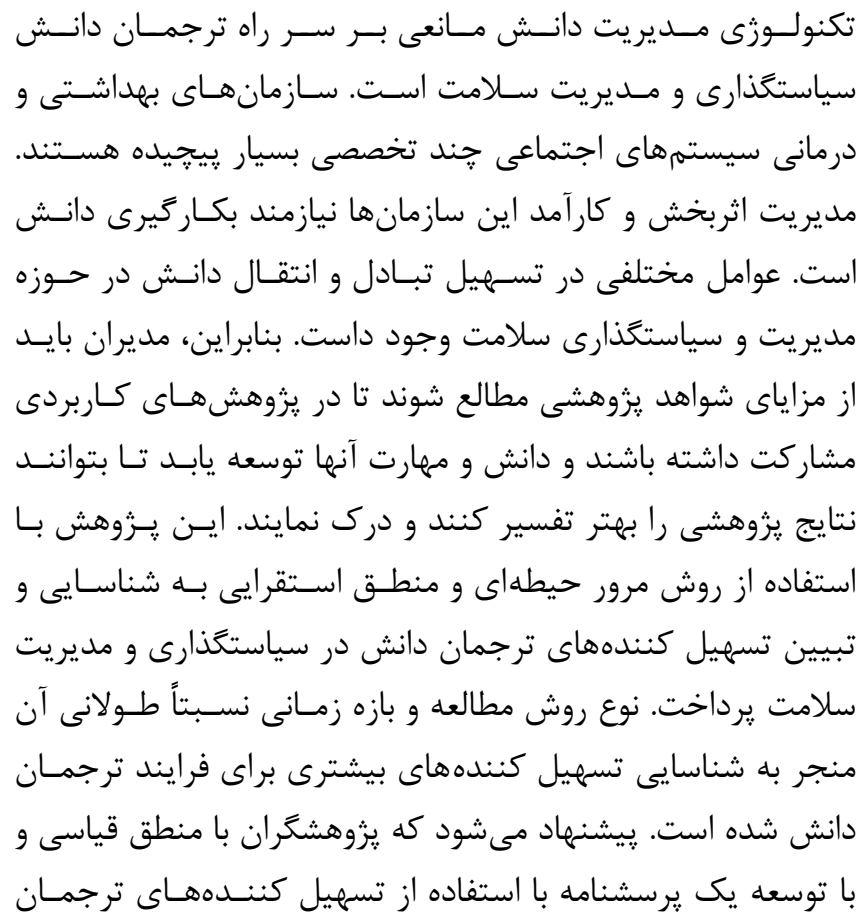

8. Chalmers I. If evidence-informed policy works in practice, does it matter if it doesn't work in theory? Evid Policy 2005; 1:227-42

9. Santesso N, Tugwell P. Knowledge Translation in Developing Countries. The Journal of Continuing Education in the Health Professions 2006; 26:87-96

10. Hewison A. Evidence-based Medicine: What about Evidence-based Management? Journal of Nursing Management 1997; 5:195-8

11. Hilal N, Harb S, Jamal D, El-Jardali F. The use of evidence in decision making by hospital managers in Lebanon: A cross-sectional study. The International journal of health planning and management. The International journal of Health Planning and Management 2020; 35:45-55

12. Innvaer $\mathrm{S}$, Vist $\mathrm{G}$, Trommald $\mathrm{M}$, Oxman A. Health policy-makers' perceptions of their use of evidence: a systematic review. Journal of Health Services Research \& Policy 2002; 7: 239-44

13. Oliver K, Innvar S, Lorenc T, Woodman J, Thomas J. A systematic review of barriers to and facilitators of the use of evidence by policymakers. BMC Health Services Research 2014; 14:2

14. Mosadeghrad AM, Tolouei Rakhshan Sh, Afshari A, Isfahani P. Health financing system 
indicators: A scoping review. Hakim Health Sys Res 2020;20; 353-366

15. Arksey H, O'Malley L. Scoping studies: towards a methodological framework, International Journal of Social Research Methodology 2005; 8:1932

16. Braun V, Clarke V. Using thematic analysis in psychology. Qualitative research in psychology. Qualitative Research in Psychology 2006; 3:77-101

17. Tricco AC, Lillie E, Zarin W, O'Brien KK, Colquhoun H, Levac D, Moher D, Peters MD, Horsley T, Weeks L, Hempel S. PRISMA extension for scoping reviews (PRISMA-ScR): checklist and explanation. Annals of Internal Medicine 2018; 169:467-73

18. Ward A, Ladd MA. An investigation of environmental factors influencing knowledge transfer. Journal of Knowledge Management Practice 2002: 32

19. Aro AR, Repopa Consortium, Bertram M, REPOPA Consortium, Hämäläinen RM, Repopa Consortium, Van De Goor I, Repopa Consortium, Skovgaard T, Repopa Consortium, Valente A. Integrating research evidence and physical activity policy making - REPOPA project. Health Promotion International 2015; 31:430-9

20. Hilal N, Harb S, Jamal D, El-Jardali F. The use of evidence in decision making by hospital managers in Lebanon: A cross-sectional study. The International Journal of Health Planning and Management 2020; 35:45-55

21. Dobbins M, Greco L, Yost J, Traynor R, Decorby-Watson K, Yousefi-Nooraie R. A description of a tailored knowledge translation intervention delivered by knowledge brokers within public health departments in Canada. Health Research Policy and Systems 2019;17:63

22. Choi BC, Pang T, Lin V, Puska P, Sherman G, Goddard M, Ackland MJ, Sainsbury P, Stachenko S, Morrison H, Clottey C. Can scientists and policy makers work together?. Journal of Epidemiology \& Community Health 2005; 59:632-7

23. Armstrong R, Waters E, Moore L, Dobbins M, Pettman T, Burns C, Swinburn B, Anderson L, Petticrew M. Understanding evidence: a statewide survey to explore evidence-informed public health decision-making in a local government setting. Implementation Science 2014; 9:188

24. Hyder AA, Corluka A, Winch PJ, ElShinnawy A, Ghassany H, Malekafzali H, Lim MK, Mfutso-Bengo J, Segura E, Ghaffar A. National policy-makers speak out: are researchers giving them what they need?. Health Policy and Planning 2011; 26:73-82

25. Mosadeghrad AM. Essentials of healthcare organization and management, $1^{\text {st }}$ edition, Tehran: Dibagran Tehran; 2015 [Persian]

26. Belkhodja O, Amara N, Landry R, Ouimet M. The extent and organizational determinants of research utilization in Canadian health services organizations. Science Communication 2007; 28: 377-417

27. Traynor R, DeCorby K, Dobbins $M$. Knowledge brokering in public health: a tale of two studies. Public Health 2014;128: 533-44

28. Bornbaum CC, Kornas K, Peirson L, Rosella LC. Exploring the function and effectiveness of knowledge brokers as facilitators of knowledge translation in health-related settings: a systematic review and thematic analysis. Implementation Science 2015; $10: 1-2$

29. Mosadeghrad A.M. The impact of organizational culture on the successful implementation of total quality management. The TQM Magazine 2006; 18: 606-25

30. Holsapple CW, Joshi KD. An investigation of factors that influence the management of knowledge in organizations. Journal of Strategic Information Systems 2009; 9: 235-261

31. Ellen ME, Horowitz E, Vaknin S, Lavis JN. Views of health system policymakers on the role of research in health policymaking in Israel. Israel Journal of Health Policy Research 2016;5: 24

32. Weatherly H, Drummond M, Smith D: Using evidence in the development of local health policies. Some evidence from the United Kingdom. International Journal of Technology Assessment in Health Care 2002; 18: 771-781

33. Hennink M, Stephenson R. Using Research to Inform Health Policy: Barriers and Strategies in Developing Countries. Journal of Health Communication 2005; 10:163-80

34. Jakobsen MW, Karlsson LE, Skovgaard T, Aro AR. Organisational factors that facilitate research use in public health policy-making: a scoping review. Health Research Policy and Systems 2019; 17: 90

35. Tricco AC, Cardoso R, Thomas SM, Motiwala S, Sullivan S, Kealey MR, Hemmelgarn B, Ouimet M, Hillmer MP, Perrier L, Shepperd S. Barriers and facilitators to uptake of systematic reviews by policy makers and health care managers: a scoping review. Implementation Science 2015;11:4 
36. Langlois EV, Mancuso A, Elias V, Reveiz L. Embedding implementation research to enhance health policy and systems: a multi-country analysis from ten settings in Latin America and the Caribbean. Health Research Policy and Systems 2019; 17: 85

37. Holmes BJ, Schellenberg M, Schell K, Scarrow G. How funding agencies can support research use in healthcare: an online province-wide survey to determine knowledge translation training needs. Implementation Science 2014; 9: 71

38. Norton TC, Howell C, Reynolds C. Exploratory study of the role of knowledge brokers in translating knowledge to action following global maternal and newborn health technical meetings. Public health 2016; 140:235-43

39. Willison DJ, MacLeod SM. The role of research evidence in pharmaceutical policy making: evidence when necessary but not necessarily evidence. Journal of Evaluation in Clinical Practice 1999; 5: 243-9

40. Ellen ME, Lavis JN, Ouimet M, Grimshaw J, Bédard PO. Determining research knowledge infrastructure for healthcare systems: A qualitative study. Implementation Science 2011; 6: 60

41. Khalid AF, Lavis JN, El-Jardali F, Vanstone M. Supporting the use of research evidence in decision-making in crisis zones in low-and middleincome countries: a critical interpretive synthesis. Health Research Policy and Systems 2020; 18:1-2

42. Panisset U, Koehlmoos TP, Alkhatib AH, Pantoja T, Singh P, Kengey-Kayondo J, McCutchen B, Miguel GB. Implementation research evidence uptake and use for policy-making. Health Research Policy and Systems 2012;10: 20

43. Abrahamson E. Management Fashion. Academy of Management Review 1996; 21:254-85

44. Walshe K, Rundall TG. Evidence based management: from theory to practice in health care. The Milbakn Quarterly 2001; 79: 429-457

45. Damschroder LJ, Aron DC, Keith RE, Kirsh SR, Alexander JA, Lowery JC. Fostering implementation of health services research findings into practice: a consolidated framework for advancing implementation science. Implementation science 2009; 4: 50
46. Clancy CM, Cronin K. Evidence-based decision making: global evidence, local decisions. Health Affairs 2005; 24:151-62

47. Archibald MM, Ambagtsheer R, Beilby J, Chehade MJ, Gill TK, Visvanathan R, Kitson AL. Perspectives of Frailty and Frailty Screening: protocol for a collaborative knowledge translation approach and qualitative study of Stakeholder Understandings and Experiences. BMC geriatrics 2017; 17: 87

48. Bowen S, Martens P. Demystifying knowledge translation: learning from the community. Journal of Health Services Research and Policy 2005; 10: 203-211

49. El-Jardali F, Lavis JN, Ataya N, Jamal D. Use of health systems and policy research evidence in the health policymaking in eastern Mediterranean countries: views and practices of researchers. Implementation Science 2012; 7: 2

50. Boyko JA, Lavis JN, Abelson J, Dobbins M, Carter N. Deliberative dialogues as a mechanism for knowledge translation and exchange in health systems decision-making. Social Science \& Medicine 2012; 75:1938-45

51. Gagnon ML. Moving knowledge to action through dissemination and exchange. Journal of Clinical Epidemiology 2011;64: 25-31

52. Bogenschneider $\mathrm{K}$, Olson JR, Linney $\mathrm{KD}$, Mills J. Connecting research and policymaking: Implications for theory and practice from the family impact seminars. Family Relations 2000;49: 327-39

53. Grimshaw J, Eccles $M$, Tetroe J. Implementing clinical guidelines: current evidence and future implications. Journal of Continuing Education in the Health Professions 2004; 24: 31-7

54. Mitton C, Adair CE, McKenzie E, Patten SB, Perry BW. Knowledge transfer and exchange: review and synthesis of the literature. The Milbank Quarterly 2007;85:729-68

55. Forrester DA, O'Keefe T, Torres S. Professor in residence program: a nursing faculty practice. Journal of Professional Nursing 2008;24: 275-80

56. Bower DJ, Reid M, Barry N, \& Ibbotson T. Aligning process and meaning: innovating in complex health care delivery systems. International Journal of Innovation Management 2000; 4: 299-318 